\title{
Atmospheric Mercury Near Salmon Falls Creek Reservoir in Southern Idaho
}

Michael L. Abbott

Che-Jin Lin

Pete Martian

Jeffrey J. Einerson

December 2007

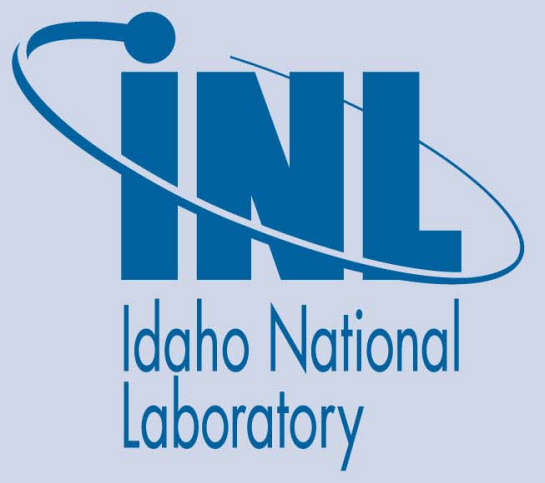

The INL is a U.S. Department of Energy National Laboratory operated by Battelle Energy Alliance 


\title{
Atmospheric Mercury Near Salmon Falls Creek Reservoir in Southern Idaho
}

\author{
Michael L. Abbott \\ Che-Jin Lin \\ Pete Martian \\ Jeffrey J. Einerson
}

December 2007

\author{
Idaho National Laboratory \\ Idaho Falls, Idaho 83415 \\ and \\ Lamar University \\ Beaumont, Texas 77710
}

Prepared for the

Idaho Department of Environmental Quality,

U.S. Environmental Protection Agency Region 10, and the U.S. Department of Energy

Under DOE Idaho Operations Office

Contract DE-AC07-05ID14517 


\section{Atmospheric Mercury near Salmon Falls Creek Reservoir in Southern Idaho}

INL/EXT-06-12048

December 2007

Approved by 



\begin{abstract}
Gaseous elemental mercury (GEM) and reactive gaseous mercury (RGM) were measured over two-week seasonal field campaigns near Salmon Falls Creek Reservoir in south-central Idaho from the summer of 2005 through the fall of 2006 and over the entire summer of 2006 using automated Tekran mercury analyzers. GEM, RGM, and particulate mercury (HgP) were also measured at a secondary site $90 \mathrm{~km}$ to the west in southwestern Idaho during the summer of 2006. The study was performed to characterize mercury air concentrations in the southern Idaho area for the first time, estimate mercury dry deposition rates, and investigate the source of observed elevated concentrations. High seasonal variability was observed with the highest GEM $\left(1.91 \pm 0.9 \mathrm{ng} \mathrm{m}^{-3}\right)$ and RGM $\left(8.1 \pm 5.6 \mathrm{pg} \mathrm{m}^{-3}\right)$ concentrations occurring in the summer and lower values in the winter $\left(1.32 \pm 0.3 \mathrm{ng} \mathrm{m}^{-3}, 3.2 \pm 2.9 \mathrm{pg} \mathrm{m}^{-3}\right.$ for GEM, RGM respectively). The summer-average $\mathrm{HgP}$ concentrations were generally below detection limit $\left(0.6 \pm 1 \mathrm{pg} \mathrm{m}^{-3}\right)$. Seasonally-averaged deposition velocities calculated using a resistance model were $0.034 \pm$ $0.032,0.043 \pm 0.040,0.00084 \pm 0.0017$ and $0.00036 \pm 0.0011 \mathrm{~cm} \mathrm{~s}^{-1}$ for GEM (spring, summer, fall, and winter, respectively) and $0.50 \pm 0.39,0.40 \pm 0.31,0.51 \pm 0.43$ and $0.76 \pm 0.57 \mathrm{~cm} \mathrm{~s}^{-1}$ for RGM. The total annual RGM + GEM dry deposition estimate was calculated to be $11.9 \pm 3.3$ $\mu \mathrm{g} \mathrm{m}^{-2}$, or about $2 / 3$ of the total (wet + dry) deposition estimate for the area. Periodic elevated short-term GEM $\left(2.2-12 \mathrm{ng} \mathrm{m}^{-3}\right)$ and RGM (50 - $\left.150 \mathrm{pg} \mathrm{m}^{-3}\right)$ events were observed primarily during the warm seasons. Back-trajectory modeling and PSCF analysis indicated predominant source directions from the southeast (western Utah, northeastern Nevada) through the southwest (north-central Nevada) with fewer inputs from the northwest (southeastern Oregon and southwestern Idaho).
\end{abstract}




\section{ACKNOWLEDGMENTS}

We are indebted to Sage Aslet for allowing us to do our air sampling on his ranch at House Creek from July 2005 through October 2006. He was a great host and friend throughout the work. We also thank the professional and very friendly USAF staff at the Grasmere EC site for our access there during the summer of 2006. Agency staff who provided significant contribution on this work include Mike Dubois at the Idaho DEQ, and Leigh Woodruff, Bob Kotchenruther, and Madonna Narvaez at EPA Region 10. We also greatly appreciate the outstanding and prompt technical support provided by Frank Schaedlich and Gabe Eiras of Tekran, Inc. The authors gratefully acknowledge the NOAA Air Resources Laboratory (ARL) for the provision of the HYSPLIT transport and dispersion model and READY website (http://www.arl.noaa.gov/ready.html) used in this publication. The findings in this report have been accepted for publication in the peer-reviewed journal, Applied Geochemistry (March 2008). The report has not received formal EPA peer-review, and should not be construed as official U.S. Environmental Protection Agency or Idaho DEQ position, policy, or decision. 


\section{Atmospheric Mercury near Salmon Falls Creek Reservoir in Southern Idaho}

\section{Introduction}

Salmon Falls Creek Reservoir (SFCR) in remote south-central Idaho has mercury (Hg) contamination problems similar to many other water bodies in the U.S. (Driscoll et al., 1994; Mason and Sullivan, 1997; Kang et al., 2000; Vette et al., 2002; Gao et al., 2006). In 2005, the Idaho Department of Environmental Quality (DEQ) began a multi-media (water, sediment, precipitation, air) sampling effort in an effort to identify the possible source(s) of $\mathrm{Hg}$ contamination in SFCR. This paper reports the results of atmospheric $\mathrm{Hg}$ measurements in the SFCR study. Atmospheric transport and deposition is known to be a primary transport pathway for $\mathrm{Hg}$ to watersheds and water bodies especially in remote areas that are not subject to direct surface discharges from nearby sources (Swain et al., 1992; Mason et al., 1994; Lockhart et al., 1995; Engstrom and Swain, 1997; Schroeder and Munthe, 1998; Fitzgerald et al., 1998).

Atmospheric $\mathrm{Hg}$ in the western U.S. may originate from numerous documented sources, including global (trans-Pacific) sources (Jaffe et al., 2005, Weiss-Penzias et al., 2006), volcanoes (Schuster et al., 2002), evasion from naturally-enriched substrates and geothermal areas (Gustin, 2003), regional wildfires (Friedli et al., 2003), and anthropogenic combustion, cement production, and mining emission sources in Idaho and adjacent states (USEPA, 1998). According to the U.S. Environmental Protection Agency's (EPA) Toxic Release Inventory (TRI) (http://www.epa.gov/tri/), reported industrial emissions of $\mathrm{Hg}$ in Idaho and other western states totaled 5.1 Mg in 2004, with the following breakdown: Nevada (2.2 Mg), California (1.8 $\mathrm{Mg})$, Utah (0.41 Mg), Oregon (0.36 Mg), and Idaho (0.33 Mg). The largest of these sources are the gold mining activities in northern Nevada (2.1 Mg reported, not counting fugitive 
emissions), the closest of which is $120 \mathrm{~km}$ southwest of SFCR. The largest Hg source in Idaho is a phosphate (P4) plant $300 \mathrm{~km}$ east of SFCR in Soda Springs, ID which reports $0.3 \mathrm{Mg} \mathrm{y}^{-1}$. In addition to these anthropogenic emissions, there are other unreported sources of $\mathrm{Hg}$ in the region which could contribute to local and regional atmospheric Hg loading (e.g., naturallyenriched areas, geothermal areas, wildfires).

$\mathrm{Hg}$ deposition rate at a particular location is a function of several factors, including the air concentrations of the three predominant $\mathrm{Hg}$ species (RGM, HgP, or GEM), wet deposition processes, such as rainfall rates and aqueous mercury concentrations (Guentzel et al., 2001), and dry deposition processes, which vary depending on the terrain, type of vegetation, and meteorology (Seinfeld and Pandis, 1998). For arid locations in the western U.S., dry deposition has been found to be a significant contributor to total deposition (Lyman, et al., 2007; Caldwell et al., 2006). Since gaseous Hg deposition rates are difficult to directly measure (Lyman et al, 2007) and are highly variable over space and time (diurnally and seasonally), long-term depositional studies often "infer" them as the product of the speciesspecific air concentrations and an empirical deposition velocity $\left(V_{d}\right)$. Hourly $V_{d}$ is often calculated using a resistance model, on-site meteorology, and site-specific land use parameters (Lindberg et al., 1992; Pai et al., 1997, 1999; Lin et al., 2006).

The primary objectives of this study were to obtain seasonal measurements of Hg air concentrations in the SFCR area and to estimate seasonal and annual dry deposition rates in the area. Mercury air concentrations had not been measured previously in southern Idaho, although some measurements have been made in southeastern Idaho on the Snake River Plain $200 \mathrm{~km}$ to the northeast (Abbott, 2003). A secondary objective was to identify the sources of Hg that may be contributing to elevated $\mathrm{Hg}$ air concentrations in the area. 


\section{Field sites}

SFCR lies in extreme south-central Idaho, approximately $50 \mathrm{~km}$ southwest of Twin Falls and $10 \mathrm{~km}$ north of the Nevada border (Figure 1). The reservoir is long $(17 \mathrm{~km})$ and narrow $(0.4 \mathrm{~km})$, has a storage capacity of $0.3 \mathrm{~km}^{3}$, and is primarily used for agricultural irrigation, fishing, and recreation. The reservoir lies at an elevation of $1510 \mathrm{~m}$ on the southern edge of the Snake River Plain in a broad $(20 \mathrm{~km})$, flat valley surrounded on the east and west by $500-\mathrm{m}$ high hills. It has a very large watershed catchment/lake surface area ratio of $\sim 500$ and is annually charged by relatively rapid snowmelt runoff from the upper basin in the spring. Engstrom and Swain (1997) found that rural Minnesota lakes with larger catchments (relative to lake area) had higher total $\mathrm{Hg}$ loading, suggesting that catchments may be important to consider when assessing Hg deposition.
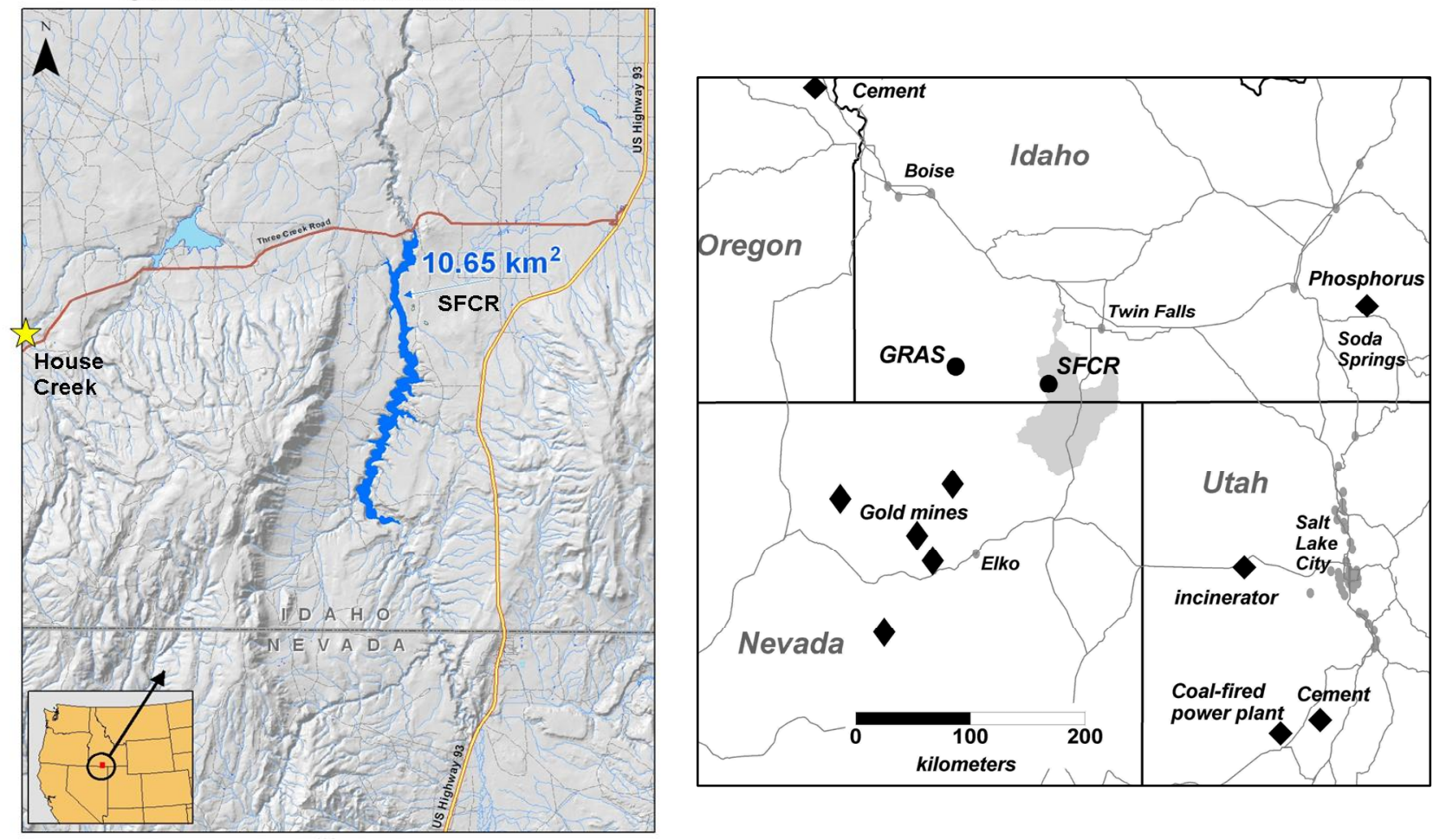

Figure 1. Salmon Falls Creek Reservoir (SFCR) and surrounding area. 
The average annual precipitation in the area is $28 \mathrm{~cm}$ giving the area a relatively dry semiarid steppe climate with vegetation dominated by grasses and mixed shrubs (sagebrush and rabbitbrush, $<50 \mathrm{~cm}$ high) with very few trees. Summers are warm (daytime highs $\sim 30^{\circ} \mathrm{C}$ ) and dry with isolated thunderstorms. Winter temperatures range around $0^{\circ} \mathrm{C}$ with infrequent minor $(\sim 1 \mathrm{~cm})$ snowfall.

Most of the air sampling was performed at a private ranch (House Creek, elevation 1734 m) located $28 \mathrm{~km}$ west of the SFCR dam in the northwestern part of the Salmon Falls watershed (Figure 1). Site vegetation and topography are very similar to the SFCR area with relatively flat rangeland surrounding the site and 500-m high hills $12 \mathrm{~km}$ to the south. The site was selected because it provided a secure, remote location with power and an open unobstructed airshed. Winds are predominantly from the northwest through southwest, although periods of southeasterly airflow may occur, especially in the summer months.

The sampling site is approximately $120 \mathrm{~km}$ northeast of the closest Nevada gold mine (Jerritt Canyon), $300 \mathrm{~km}$ west of the P4 phosphate plant near Soda Springs, Idaho, and $320 \mathrm{~km}$ southeast of a large cement plant source in eastern Oregon (Figure 1). In addition to these anthropogenic sources, there are diffuse naturally-enriched $\mathrm{Hg}$ sources to the southwest in northern Nevada including several large historic Hg mines. The nearest populated community is the town of Twin Falls, Idaho (population 38,630), $67 \mathrm{~km}$ to the northeast. There are no sizeable communities or known local $\mathrm{Hg}$ emission sources within $50 \mathrm{~km}$ of the site, and there has been very little mining activity in the south-central Idaho region.

Speciated air sampling for GEM and RGM was performed at the House Creek site over 2 week periods during the summer and fall of 2005 (July 22 - August 5; November 1- 15) and the spring of 2006 (May 24 - June 8). Mid-winter sampling (February 8 -23, 2006) was 
moved to the SFCR dam, $28 \mathrm{~km}$ to the east, for easier access. After completion of the seasonal sampling campaigns in the spring of 2006, a long-term (mid-June through mid-August 2006) summer sampling effort was performed concurrently at the House Creek site and a remote secondary site (U.S. Air Force Grasmere EC site) in southwestern Idaho, $83 \mathrm{~km}$ west of House Creek (June 13 - July 18) (Figure 1). Sampling at Grasmere (GRAS) was performed to assess the variability of $\mathrm{Hg}$ air concentrations across southern Idaho and to better understand the source of elevated air concentration events observed at SFCR during the previous seasonal sampling campaigns. The GRAS site was selected because it is very similar (elevation, latitude, topography, vegetation) to SFCR area and was the only secure and accessible location available in remote southwestern Idaho with power. At the completion of the summer 2006 sampling campaign in mid-August, additional GEM-only sampling was performed at House Creek from September 15 - October 18, 2006 to investigate whether GEM inputs decreased after the wildfire season was over.

\section{Methods and materials}

\subsection{Speciated air concentrations}

Continuous 5-min average GEM and 80-min (60-min in summer of 2006) average RGM measurements at the House Creek site were made using the Idaho National Laboratory (INL) Tekran ${ }^{1}$ 2537A mercury vapor analyzer and Tekran ${ }^{\circledR} 1130$ speciation unit (denuder module) operated out of a temperature-controlled $7 \times 14-\mathrm{ft}$ instrument trailer (Figure 2). The sample inlet for both the RGM and GEM measurement was $4 \mathrm{~m}$ above ground level. The INL system does not have a Tekran 1135 (HgP) unit; therefore $\mathrm{HgP}$ was not measured at the House Creek

\footnotetext{
${ }^{1}$ References herein to any specific commercial product, process, or service by trade name, trademark, manufacturer, or otherwise, does not necessarily constitute or imply its endorsement, recommendation, or favoring by the U.S. Government, any agency thereof, or any company affiliated with the Idaho National Laboratory.
} 
site. Sampling at GRAS in the summer of 2006 used a similar Tekran system borrowed from EPA Region 9 (EPA9) with the addition of a Tekran 1135 unit for the measurement of HgP.

The 1135 uses a regenerable quartz filter to trap fine particulate less than $2.5 \mu \mathrm{m}$ downstream from the 1130 denuder module, giving a 60 -min average $\mathrm{HgP}$ measurement every two hours. Additional details on these Tekran systems are contained in numerous other publications (e.g., Landis et al., 2002; Poissant et al., 2004, 2005).

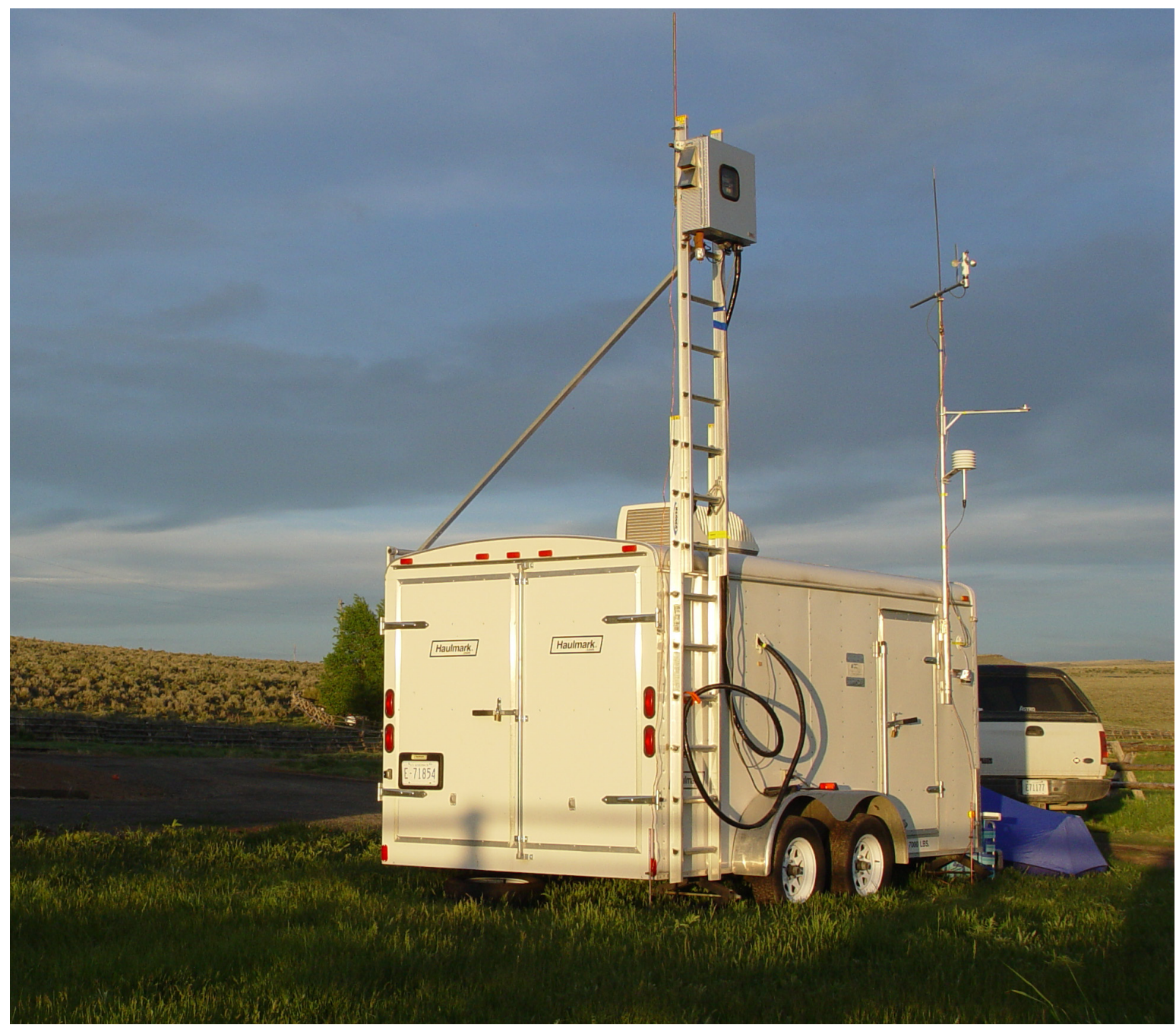

Figure 2. INL Tekran trailer at the SFCR (House Creek) sampling site. 


\section{$3.2 Q A / Q C$}

Both Tekran systems were calibrated daily against an internal permeation source and fully calibrated with precisely-known $\mathrm{Hg}$ vapor injections (using a Tekran 2505 unit) at 6 month (or less) intervals. The mass flow controller on the INL Tekran 2537A was verified twice during the sampling campaigns (using a Gillibrator- $2{ }^{1}{ }^{1}$ ) and found to be within $2 \%$ of indicated. Biweekly maintenance was performed on the system which included: (1) complete sampling system bias checks consisting of blank (zero air) runs and standard addition recoveries through the sample line, filters, and 2537A, (2) replacement of all filters in the sample lines, denuder module, and 2537A, and (3) replacement of the denuder with a freshly-coated, blanked one. All of these checks showed good (zero) system blanks and percent recoveries typically ranging from $95-105 \%$. Mean RGM and HgP blank values ranged from $0.11 \mathrm{pg} \mathrm{m}^{-3}$ (winter 06) to 1.2 $\mathrm{pg} \mathrm{m}^{-3}$ (Spring 06). All RGM and HgP measurements were blank corrected by subtracting three times the last zero air sample cycle results prior to desorption from the sum of the three $\mathrm{RGM} / \mathrm{HgP}$ sample cycle results.

The precision of the 2537A was estimated to be $<6 \%$ using repetitive $\mathrm{Hg}$ vapor injections from the Tekran 2505 calibration unit. The method detection limit (MDL) for GEM is $<0.1 \mathrm{ng}$ $\mathrm{m}^{-3}$ (Tekran, 1999), much lower than typical background GEM concentrations $\left(\sim 1.5 \mathrm{ng} \mathrm{m}^{-3}\right)$. The MDL for RGM and HgP is calculated as 3 times the standard deviation of the zero-air cycle field blanks (Landis et al., 2002). At House Creek, the MDL for RGM was calculated to be $5.4 \mathrm{pg} \mathrm{m}^{-3}(\mathrm{n}=1435)$. At GRAS, the MDL for RGM and $\mathrm{HgP}$ was calculated to be $3.3 \mathrm{pg}$ $\mathrm{m}^{-3}(\mathrm{n}=844)$. At the conclusion of the sampling, a 3-day collocated precision test was performed in the field with both Tekran systems sampling the same air through a heated Teflon manifold. The median relative errors (MRE, calculated using NADP protocol) for this field test 
were $4.0 \%$ for GEM and 19\% for RGM (1-hr samples, $\mathrm{n}=33$ ). The standard deviations of the relative errors were 5.4\% (GEM) and 15.9\% (RGM). These results compare well with a controlled laboratory test by Landis et al. (2002), who measured a mean collocated precision of $15 \pm 9.3 \%$ for RGM using manual denuders. Regression plots (Figure 3) show random unbiased differences about the regression line for both GEM and RGM, although the RGM slope (1.23) indicates some systematic difference between the two systems.
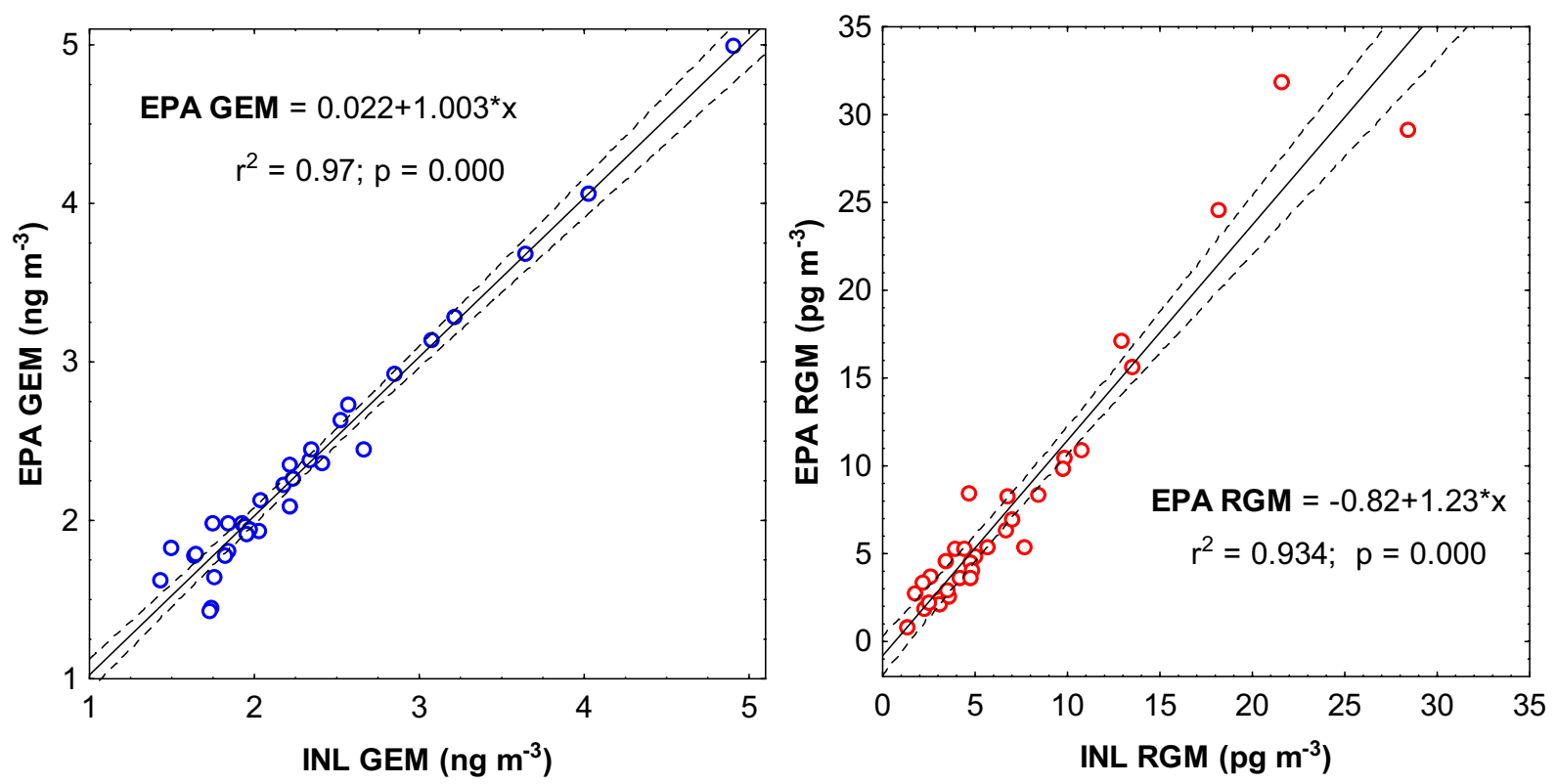

Figure 3. Co-located precision test results between the INL and EPA Tekran systems.

During the summer of 2006, temporary gold cartridge passivation was intermittently observed on some of the first few 5-min GEM sampling cycles following the RGM desorption cycle, resulting in depressed GEM values $\left(<0.5 \mathrm{ng} \mathrm{m}^{-3}\right)$ for those samples. Gold cartridge passivation has been reported by other researchers (e.g., Landis et al., 2002; Hall et al., 2006) and seems to be a fairly common problem especially during longer-term sampling. Two possible sources for this passivation have been reported by other Tekran users-water 
vapor/iodine from the 1130 pump module and unknown constituents in ambient air. Bi-weekly standard additions routinely showed good (95-105\%) recoveries, and most of passivated 5-min samples were identified and removed. However, because of the bias potential, none of the summer 2006 data were used for calculation of dry deposition rates. They were however used for conservative assessment of elevated peak events which were observed throughout the summer.

\subsection{Other atmospheric measurements}

Ozone concentrations were measured at the House Creek site primarily during the summer of 2006 using a 2B Technologies ${ }^{\circledR}$ Model 202 Ozone Monitor (Golden, Colorado ${ }^{1}$ ). A comprehensive set of meteorological parameters were measured including wind direction/wind speed (WD/WS), relative humidity/air temperature (AT/RH), solar radiation (SR), and barometric pressure (BP) (Met One Instruments ${ }^{\circledR}{ }^{1}$, Grants Pass, Oregon). WD/WS measurements were made at the same height as the $\mathrm{Hg}$ measurements $(4 \mathrm{~m})$.

\subsection{Dry deposition}

The deposition of GEM and RGM over the four seasonal sampling campaigns (summer 2005 through spring 2006) was estimated through the product of the deposition velocity and gaseous concentration (Seinfeld and Pandis, 1998):

$$
F_{d r y}=-V_{d} \times C_{g}
$$

where $F_{d r y}$ is the dry deposition flux $\left(\mathrm{ng} \mathrm{m}^{-2} \mathrm{hr}^{-1}\right), V_{d}$ is the dry deposition velocity $\left(\mathrm{m} \mathrm{s}^{-1}\right)$ and $C_{g}$ is the gaseous concentration of GEM or RGM in $\mathrm{ng} \mathrm{m}^{-3}$. With the measured hourly metrological parameters, the site-specific hourly $V_{d}$ for GEM and RGM was calculated using the resistance model:

$$
V_{d}=\left(R_{a}+R_{b}+R_{c}\right)^{-1}
$$


where $R_{a}\left(\mathrm{~s} \mathrm{~m}^{-1}\right)$ is the aerodynamic resistance estimated from turbulent transport, $R_{b}\left(\mathrm{~s} \mathrm{~m}^{-1}\right)$ is the quasi-laminar resistance estimated from mercury diffusivities and air density, and $R_{c}\left(\mathrm{~s} \mathrm{~m}^{-1}\right)$ is the canopy/surface resistance estimated from the properties of the depositing species and surface.

The aerodynamic resistance $\left(R_{a}\right)$ is given by (Ganzeveld and Lelieveld, 1995):

$$
R_{a}=\frac{1}{u_{*} k}\left[\ln \left(\frac{z-d}{z_{0}}\right)-\Psi\left(\frac{z-d}{L}\right)\right]
$$

where $u_{*}$ is the friction velocity $\left(\mathrm{m} \mathrm{s}^{-1}\right), k$ is the von Karman's constant $(\approx 0.4), z(\mathrm{~m})$ is a reference height subject to deposition corresponding to the respective stability class, $z_{o}(\mathrm{~m})$ is the surface roughness which is taken as $0.05 \mathrm{~m}$ for the landuse type (Gallagher et al., 2002; Zhang et al., 2003), $d(\mathrm{~m})$ is the displacement height which is taken as zero since $d<<z$ in the calculation, $L(\mathrm{~m})$ is the Monin-Obukhov length estimated for the corresponding stability class according to Golder (1972), $\Psi$ is a dimensionless stability correction term which is calculated according to the suggestion of Seinfeld and Pandis (1998).

The quasi-laminar resistance $\left(R_{b}\right)$ and canopy/surface resistance $\left(R_{c}\right)$ were estimated using RADM deposition scheme (Wesley, 1989):

$$
\begin{aligned}
& R_{b}=\frac{5 S c^{2 / 3}}{u_{*}} \\
& R_{c}=\left(\frac{1}{r_{s x}+r_{m x}}+\frac{1}{r_{l u x}}+\frac{1}{r_{d c}+r_{c l x}}+\frac{1}{r_{a c}+r_{g s x}}\right)^{-1}
\end{aligned}
$$

where $S_{c}$ is the Schmidt number expressed as the ratio of kinematic viscosity to molecular diffusivity for the species $\mathrm{X}, \mathrm{r}_{\mathrm{sx}}$ is the stomatal resistance for trace gas species $\mathrm{X}, \mathrm{r}_{\mathrm{mx}}$ is the mysophyll resistance, $r_{\text {lux }}$ is the leaf cuticular resistance, $r_{\mathrm{dc}}$ is the buoyant convective resistance, $r_{\mathrm{clx}}$ is the lower canopy resistance, $\mathrm{r}_{\mathrm{ac}}$ is the surface bulk resistance that depends 
only on canopy height and density, $r_{g s x}$ is the ground surface resistance. The expressions of each resistance term can be found in Wesley (1989) and Lin et al., (2006).

\subsection{Flux measurements}

The dry deposition estimates determine by the above inferential model only evaluate downward (air-to-surface) flux. However, some of the deposited $\mathrm{Hg}$ may be lost due to reemission (upward flux) which is predominantly in the form of GEM. Both processes (downward and upward flux) must be quantified to estimate the net Hg surface exchange, which is needed to assess both watershed and reservoir Hg inputs. Surface-to-air (upward) flux can only be assessed using either flux chamber (e.g., Engle et al. 2001) or micrometeorological methods (Lindberg et al. 1995).

Because of the importance of understanding net $\mathrm{Hg}$ surface exchange at the SFCR site, we attempted a 7-day micrometeorological flux experiment in September 2006 to provide some measurements of both GEM and RGM fluxes. We used the modified Bowen ratio (MBR) method which has been widely used to infer trace gas (e.g., $\mathrm{Hg}$ ) fluxes from measured vertical concentration gradients and turbulent fluxes of water vapor using eddy correlation (EC) with fast-response sensors (Lindberg et al., 1995, Poissant et al., 2004). This method uses two Tekrans to simultaneously measure the GEM concentration gradients (differences) at two heights $(1.5$ and $3.5 \mathrm{~m})$ and an EC station to measure both water vapor gradient and fluxes at the same two heights (Figure 4). A turbulent transfer coefficient for water vapor flux is calculated from the EC measurements and applied to the measured $\mathrm{Hg}$ concentration gradient to calculate $\mathrm{Hg}$ flux. Higher concentrations near the ground (i.e., a positive gradient) indicate net $\mathrm{Hg}$ evasion (surface to air flux), while the reverse is true for downward deposition. To evaluate the validity of calculated $\mathrm{Hg}$ gradients relative to instrument measurement precision, a 
3-day co-located precision test between the two Tekrans was performed prior to the flux measurements (described in $Q A / Q C$ section above).
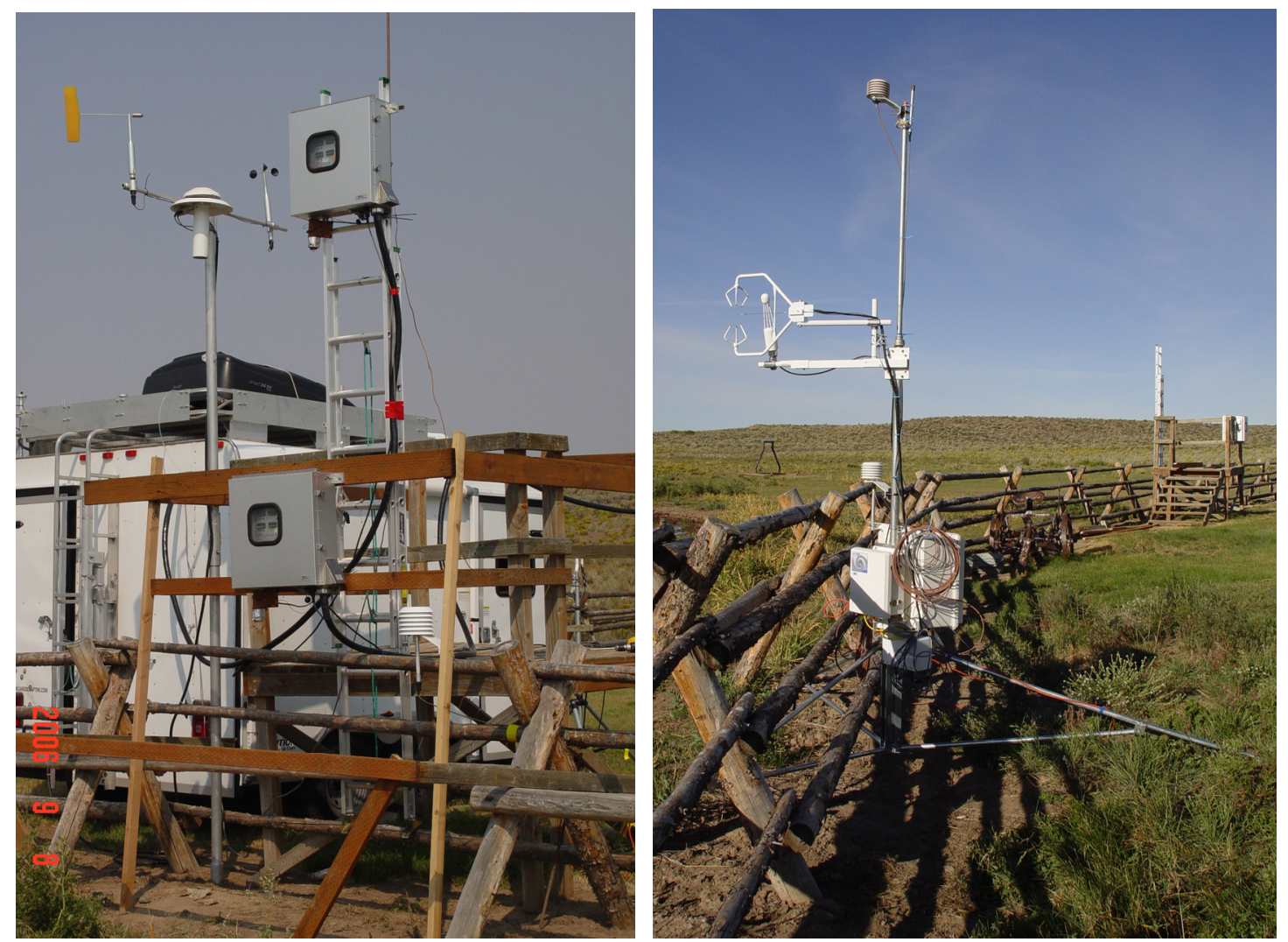

Figure 4. Micrometeorological flux test setup with dual Tekrans sampling at $1.5 \mathrm{~m}$ and $4.5 \mathrm{~m}$ heights (left) and eddy covariance (EC) station, right (measures water vapor flux and concentration gradient at same two heights).

\subsection{Back-trajectory modeling and PSCF}

Potential upwind source regions corresponding to observed GEM concentration spikes (“enhancement" events) at the sampling sites were investigated with back-trajectory modeling using the NOAA-HYSPLIT (Hybrid Single-Particle Lagrangian Integrated Trajectory) model (version 4.8) (Draxler and Rolph, 2003). Archived EDAS (Mesoscale ETA Data Assimilation System) meteorological data during the event times were used as input which has a time resolution of 3 hours and a horizontal resolution of $40 \mathrm{~km}$. For this analysis, we defined a 
GEM enhancement event as a measured concentration that exceeds trans-Pacific, coastal U.S. concentrations, suggesting possible local or regional source input. The GEM enhancement criterion used was $2.2 \mathrm{ng} \mathrm{m}^{-3}$, which is the maximum total gaseous $\mathrm{Hg}$ observed during 10 Asian transport events at the Mt. Bachelor Observatory (MBO) in central Oregon (WeissPenzias et al., 2006). Back-trajectories for RGM events were not evaluated because of its short atmospheric lifetime (Poissant et al., 2004).

GEM back-trajectories were further analyzed using a potential source contribution function (PSCF) receptor model (Ashbaugh et al., 1985; Hopke et al., 1993; Wang et al., 2006). The PSCF basically normalizes back-trajectories during events (i.e., potential upwind source areas) by the frequency of time air parcels traveled through that area over the entire sampling period. It provides a means to map the source potentials of upwind geographical areas. For this analysis, 24-hr back-trajectories were run for every hour of the sampling data, and the locations of 1-hr segment endpoints along each back-trajectory were recorded within $0.2^{\circ}$ x $0.3^{\circ}$ grid cells (approximately $33 \times 22 \mathrm{~km}$ ). The PSCF value for each grid cell was calculated as the quotient of the probability that a trajectory segment endpoint associated with a GEM event

(i.e., $>2.2 \mathrm{ng} \mathrm{m}^{-3}$ ) occurred there and the probability that the grid cell contained any segment endpoint over the entire monitoring period. Grid cells with less than 4 endpoints were eliminated from the calculation to reduce the influence of inconsequential (low frequency input) areas (Hsu et al., 2003).

\section{Results and Discussion}

\subsection{Air Concentrations}

Figure 5 shows the four seasonal concentration data sets which were used for the dry deposition modeling, and Table 1 provides a statistical comparison of the data. 

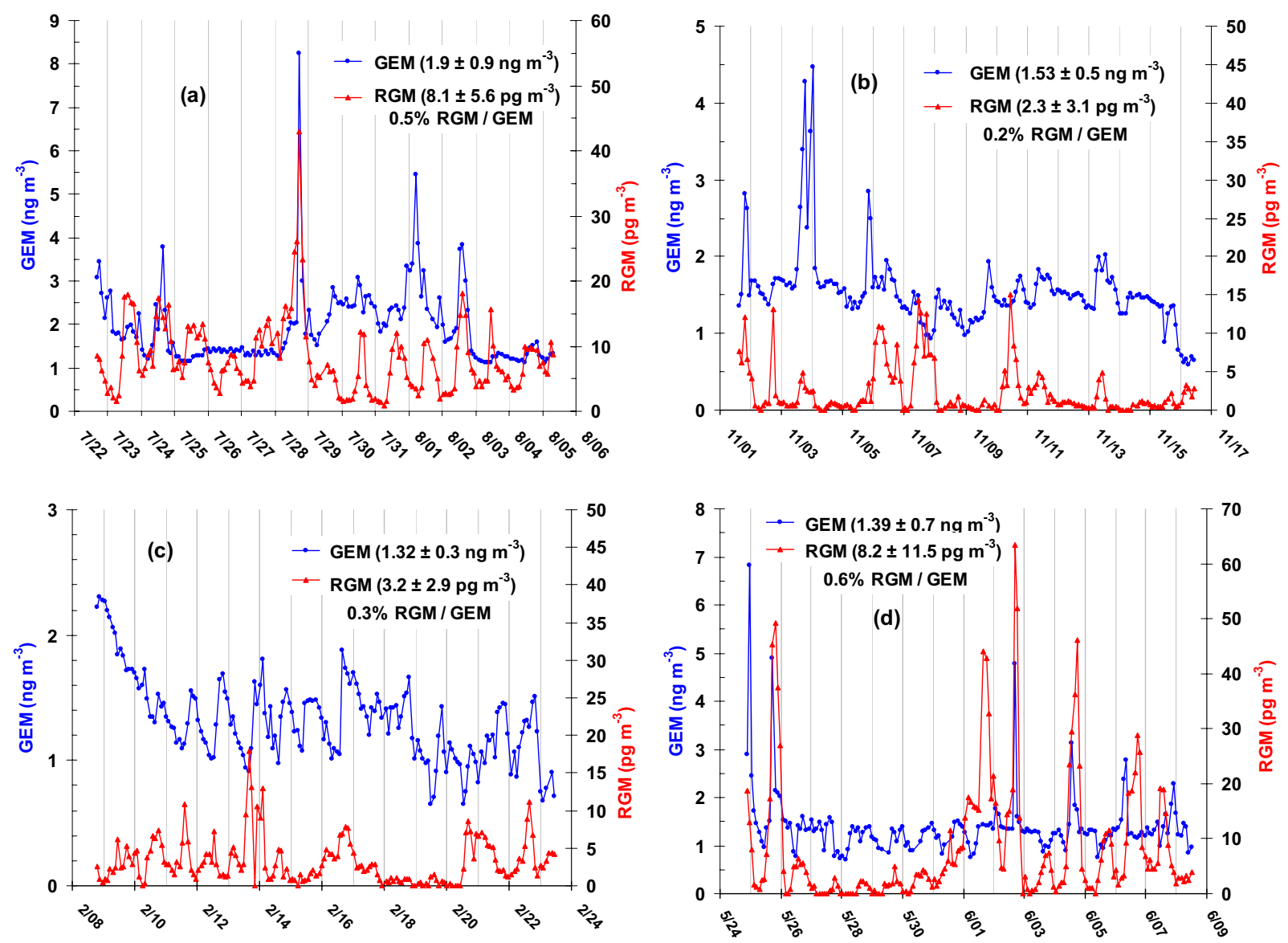

Figure 5. Two-week seasonal GEM and RGM concentrations (80-min average) measured at SFCR ( $a=$ summer 2005, $b=$ fall 2005, $c=$ winter 2006, $d=$ spring 2006).

Table 1. Statistical comparisons of seasonal data sets. Medians with different "Group" letters are significantly different from others $(\mathrm{p}<0.05)$.

\begin{tabular}{lcccccccccccc}
\multicolumn{4}{c}{ GEM } & \multicolumn{4}{c}{ RGM } & \multicolumn{4}{c}{ RGM/GEM Ratio } \\
\hline Season & $\mathbf{N}$ & $\begin{array}{c}\text { Median } \\
\left(\mathbf{n g ~ m}^{-3}\right)\end{array}$ & Group & Season & $\mathbf{N}$ & $\begin{array}{c}\text { Median } \\
\left(\mathbf{p g ~ m}^{-3}\right)\end{array}$ & Group & Season & $\mathbf{N}$ & Median & Group \\
\hline Sum 05 & 158 & 1.616 & A & Sum 06 & 760 & 10.19 & A & Sum 05 & 157 & $0.43 \%$ & A \\
Fall 06 & 660 & 1.514 & A & Sum 05 & 157 & 6.568 & B & Spg 06 & 165 & $0.30 \%$ & A \\
Fall 05 & 172 & 1.476 & A & Spg 06 & 171 & 3.922 & C & Win 06 & 171 & $0.19 \%$ & B \\
Spg 06 & 165 & 1.308 & B & Win 06 & 172 & 2.429 & D & Fall 05 & 172 & $0.06 \%$ & C \\
Win 06 & 171 & 1.304 & B & Fall 05 & 172 & 0.976 & D & & & & \\
\hline
\end{tabular}


The highest seasonal-average GEM concentrations occurred in summer 2005 (mean = 1.91 $\left.\pm 0.9 \mathrm{ng} \mathrm{m}^{-3}\right)$, followed by fall $2005\left(1.53 \pm 0.5 \mathrm{ng} \mathrm{m}^{-3}\right)$, spring $2006\left(1.39 \pm 0.7 \mathrm{ng} \mathrm{m}^{-3}\right)$, and winter $2006\left(1.32 \pm 0.3 \mathrm{ng} \mathrm{m}^{-3}\right)$. The summer and fall median GEM concentrations were statistically higher than in the spring/winter (Kruskal-Wallis test, $\mathrm{p}<0.05$ ).

For RGM, summer 2005 concentrations $\left(8.1 \pm 5.6 \mathrm{pg} \mathrm{m}^{-3}\right.$; median $\left.=6.6 \mathrm{pg} \mathrm{m}^{-3}\right)$ were statistically higher than spring $2006\left(8.2 \pm 11.5 \mathrm{pg} \mathrm{m}^{-3}\right.$; median $\left.=3.9 \mathrm{pg} \mathrm{m}^{-3}\right)$, both of which were statistically higher than fall $2005\left(2.3 \pm 3.1 \mathrm{pg} \mathrm{m}^{-3}\right)$ and winter $2006\left(3.2 \pm 2.9 \mathrm{pg} \mathrm{m}^{-3}\right)$ (Kruskal-Wallis test, $\mathrm{p}<0.05$ ). The mean seasonal RGM/GEM ratios ranged from a low of $0.2 \%$ in the fall of 2005 to a high of $0.6 \%$ in the spring of 2006 , and the mean annual ratio was $0.4 \pm 0.5 \%$. Short-term (1-h) RGM/GEM ratios at SFCR ranged up to $3.2 \%$ in the spring of 2006.

Summer 2006 mean GEM concentrations at SFCR $\left(1.19 \pm 0.8 \mathrm{ng} \mathrm{m}^{-3}\right)$ and GRAS $(1.12 \pm$ $0.9 \mathrm{ng} \mathrm{m}^{-3}$ ) (Figure 6) were lower than those measured at SFCR in the summer $2005(1.9 \pm 0.9$ $\mathrm{ng} \mathrm{m}^{-3}$ ), likely due to bias from the intermittent gold cartridge passivation (section 3.2). RGM concentrations $\left(14.8 \pm 14.5 \mathrm{pg} \mathrm{m}^{-3}, 12.1 \pm 12.5 \mathrm{pg} \mathrm{m}^{-3}\right)$ were somewhat higher and more variable than those measured in the previous summer $\left(8.1 \pm 5.6 \mathrm{pg} \mathrm{m}^{-3}\right)$. The GEM-only sampling (without the 1130-induced passivation problem) in the fall of 2006 showed a seasonal mean of $1.68 \pm 0.6 \mathrm{ng} \mathrm{m}^{-3}$ (Figure 7). 

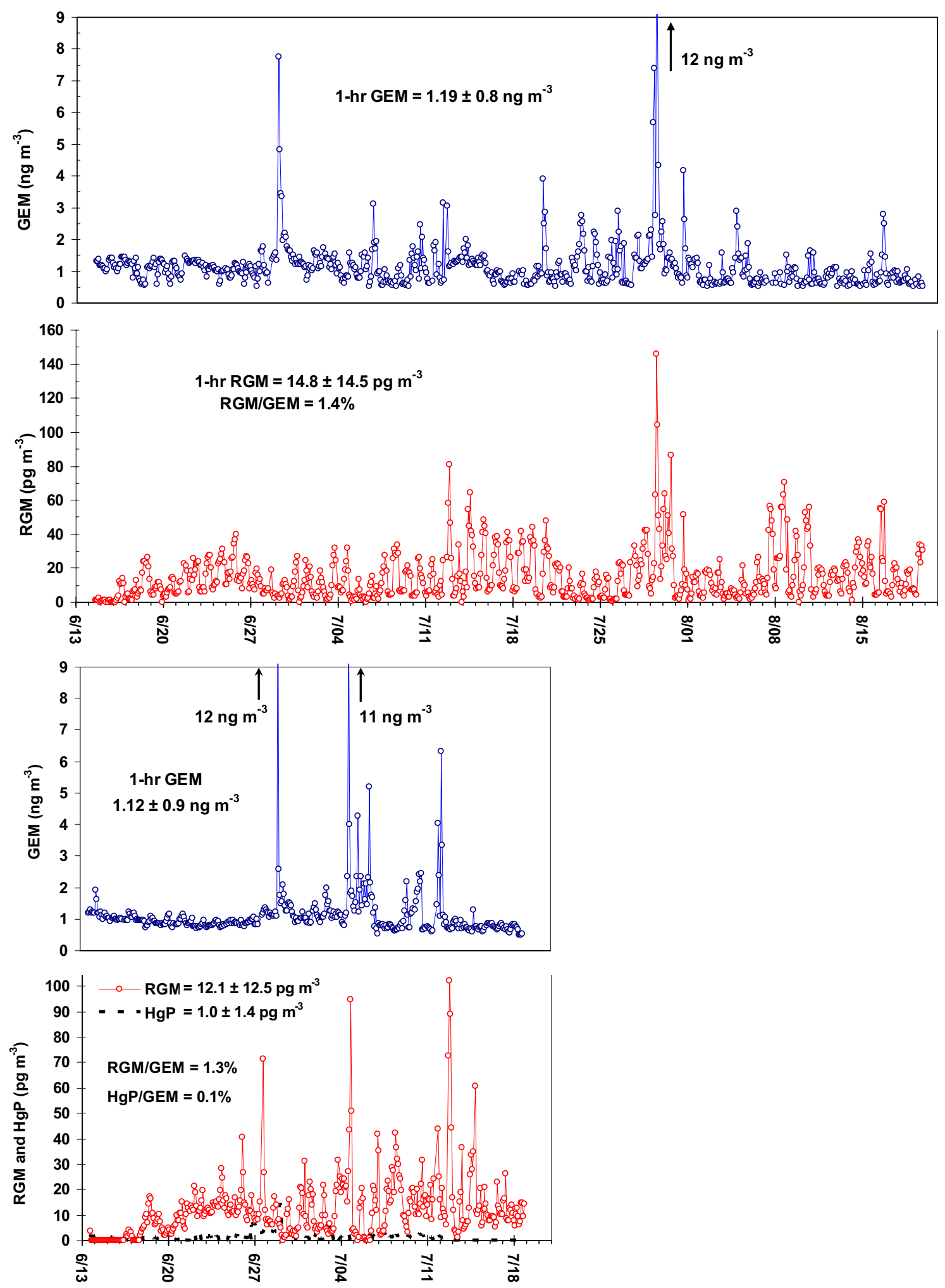

Figure 6. Summer $2006 \mathrm{Hg}$ air concentrations (80-min average) measured at SFCR (top) and GRAS (bottom). 


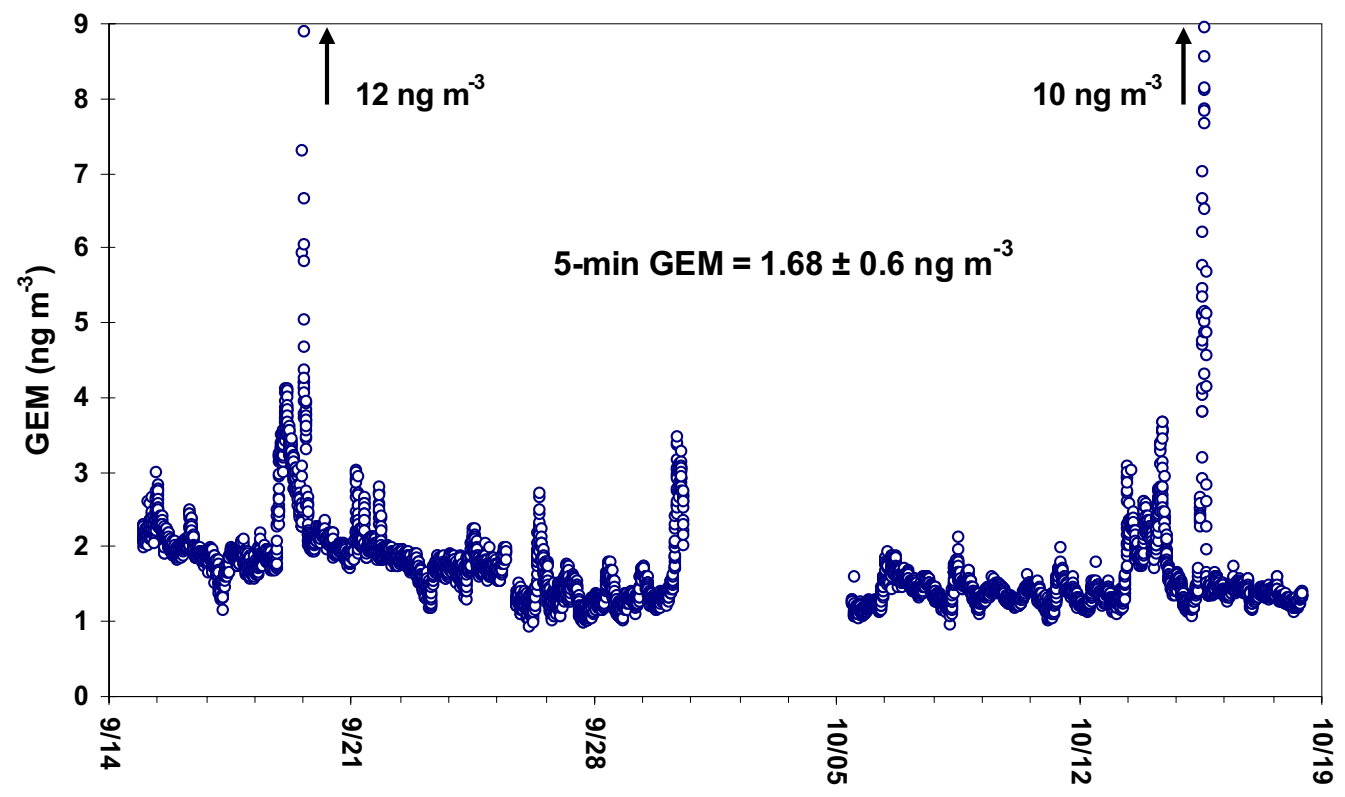

Figure 7. Fall 2006 GEM concentrations (5-min average) measured at SFCR.

Several short-term GEM enhancement events $\left(2.2-12 \mathrm{ng} \mathrm{m}^{-3}\right)$ were observed primarily in the summer and spring, with fewer events observed in the fall and winter. Most of the events were short-term (median $=5$ hours) but several lasted from $14-21$ hours during periods of stable air flow. Event frequencies (number of event samples to the total number of samples) were highest in the summer 2005 (30\%), decreasing to $4-10 \%$ during other sampling campaigns. Some of the GEM events were accompanied by relatively high $\left(40-60 \mathrm{pg} \mathrm{m}^{-3}\right)$ RGM concentrations $(7 / 28,5 / 25,6 / 2,6 / 4)$ while others $(8 / 1,11 / 3,5 / 24)$ were not. Mean RGM/GEM ratios during the events were lower than seasonal means in summer $2005(0.3 \pm$ $0.2 \%$ during events vs. $0.5 \pm 0.3 \%$ seasonal mean $)$ and winter $2006(0.05 \pm 0.04 \%$ events vs. $0.3 \pm 0.3 \%$ seasonal), but were the same in the fall and spring. The events were not associated with any particular type of weather, including the occurrence of precipitation in the region. Back-trajectories for these events are discussed in section 4.4. 


\subsection{Other atmospheric measurements}

Seasonal GEM and RGM concentrations were weakly correlated $(p<0.05)$ with several meteorological parameters, primarily air temperature and relative humidity (negative correlation). The seasonal relationships between $\mathrm{Hg}$ concentrations and air temperature are most apparent in the summer (GEM and RGM), winter (RGM), and spring (RGM) (Figure 8 and Table 2). Pollution roses show no apparent relationship between the local surface wind directions measured at the sampling site and GEM (Figure 9) and RGM concentrations (not shown but similar). This suggests that the observed elevated events are more likely due to regional sources rather than local sources, since longer transport distances are more likely influenced by curving air mass trajectories between the source and sampling site. During the summer of 2006, pronounced diel cycling of the RGM concentrations (daytime highs, nighttime lows) correlated $\left(\mathrm{r}^{2}=0.36, \mathrm{p}=0.0000\right)$ with daily changes in ozone concentrations (mean $=29.5 \pm 8.3 \mathrm{ppv}, \mathrm{n}=1030)$ suggesting the role of photochemistry in RGM production (Figure 10). 

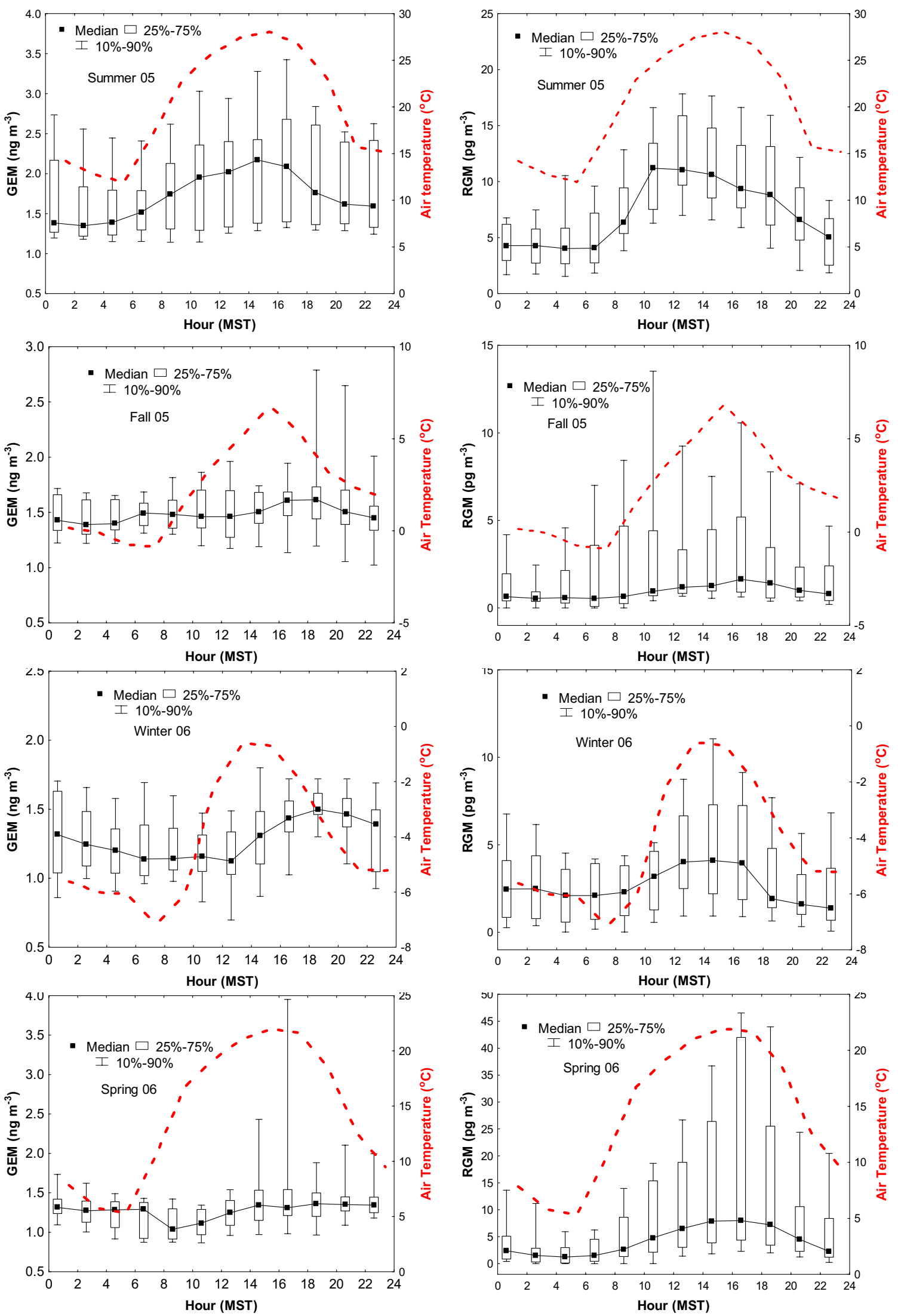

Figure 8. Hourly median GEM concentrations (with $25-75^{\text {th }}$ percentile box and $10-90^{\text {th }}$ percentile whiskers) and air temperatures at SFCR during the summer 2005 through spring 2006. 
Table 2. Correlation matrix of meteorological parameters and Hg concentrations $(\mathrm{p}<0.05)$.

\begin{tabular}{|c|c|c|c|c|c|c|c|c|}
\hline \multirow[b]{2}{*}{ Parameter } & \multicolumn{4}{|c|}{ GEM } & \multicolumn{4}{|c|}{ RGM } \\
\hline & Summer & Fall & Winter & Spring & Summer & Fall & Winter & Spring \\
\hline $\mathrm{AT}\left({ }^{\circ} \mathbf{C}\right)$ & 0.26 & 0.23 & $\mathrm{~ns}$ & 0.16 & 0.63 & 0.65 & 0.54 & 0.65 \\
\hline RH (\%) & 0.11 & -0.23 & 0.25 & -0.17 & -0.71 & -0.65 & -0.69 & -0.69 \\
\hline $\operatorname{SR}\left(\mathbf{W} \mathbf{m}^{-2}\right)$ & $\mathrm{ns}$ & ns & -0.20 & ns & 0.49 & ns & 0.31 & 0.25 \\
\hline $\mathrm{WS}\left(\mathrm{m} \mathrm{s}^{-1}\right)$ & 0.15 & 0.20 & ns & ns & 0.27 & 0.19 & 0.19 & 0.30 \\
\hline WD (deg) & 0.15 & 0.14 & $\mathrm{~ns}$ & 0.16 & ns & ns & ns & $\mathrm{ns}$ \\
\hline
\end{tabular}

ns $=$ not significant.
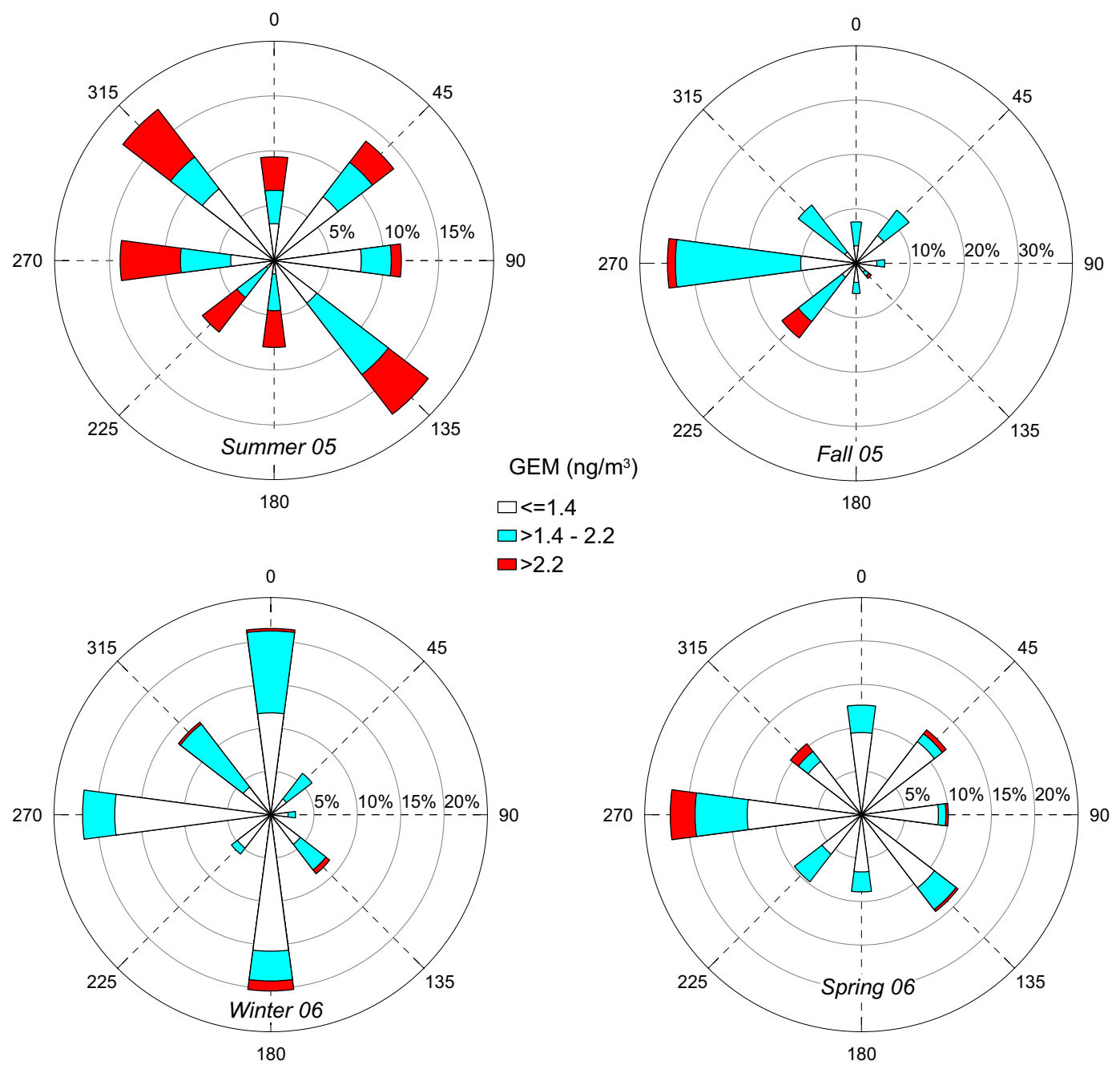

Figure 9. Pollution roses at SFCR during the summer 2005 through spring 2006. 


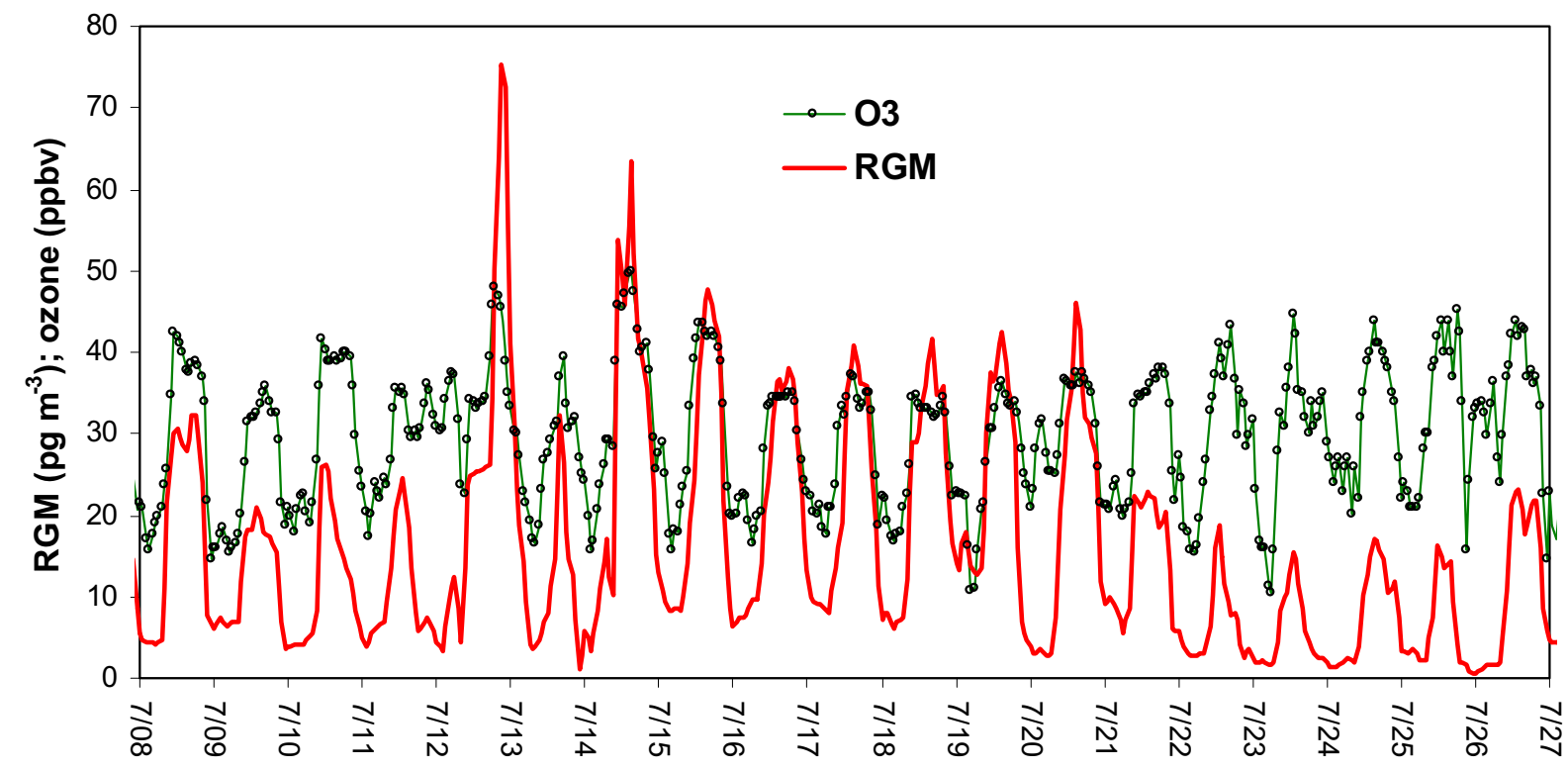

Figure 10. Diel pattern of RGM and ozone concentrations at the SFCR House Creek site during mid-summer $2006\left(r^{2}=0.36 ; p=0.0000 ; R G M=0.80 x-10.7\right)$.

\subsection{Dry deposition estimates}

The calculated $V_{d}$ for both GEM and RGM is limited either by aerodynamic resistance or canopy/surface resistance; the role of quasi-laminar resistance is not important. The mean $V_{d}$ for GEM calculated using the resistance model are $0.034 \pm 0.032,0.043 \pm 0.040,0.00084 \pm$ 0.0017 and $0.00036 \pm 0.0011 \mathrm{~cm} \mathrm{~s}^{-1}$ for spring, summer, fall, and winter, respectively. The low deposition velocities in fall and winter are caused by the high canopy/surface resistance (reduced transport from air to plant surfaces) for low-solubility trace gas such as GEM at low temperature $\left(<0{ }^{\circ} \mathrm{C}\right)$. The calculated mean $V_{d}$ for $\mathrm{RGM}$ are $0.50 \pm 0.39,0.40 \pm 0.31,0.51 \pm$ 0.43 and $0.76 \pm 0.57 \mathrm{~cm} \mathrm{~s}^{-1}$ for spring, summer, fall, and winter, respectively. The higher $V_{d}$ in winter is due to the lowered ground surface resistance caused by decreased vegetation coverage in cold seasons (Wesley, 1989). Our estimated mean $V_{d}$ is somewhat different from the regional model estimates reported by Lin et al. 2006 because the site-specific land use type and 
measured meteorology at both measurement sites were incorporated in the calculation. With the $V_{d}$, the estimated mercury dry deposition exhibits strong diurnal variation and generally peaks during daytime due to solar radiation and greater atmospheric turbulence. The estimated deposition is dominated by GEM in the warm seasons (spring and summer) and by RGM in the cold seasons (fall and winter).

The annual-average RGM dry deposition rate is $0.12 \pm 0.06 \mathrm{ng} \mathrm{m}^{-2} \mathrm{~h}^{-1}$. The total seasonal RGM deposition was calculated to be $0.44,0.33,0.12$, and $0.22 \mu \mathrm{g} \mathrm{m}^{-2}$ for spring, summer, fall, and winter, respectively (Figure 11). The annual RGM dry deposition is the sum of these, $1.1 \pm 0.1 \mu \mathrm{g} \mathrm{m}^{-2}$. $\mathrm{HgP}$ at GRAS was generally less than detection limit, giving an insignificant dry deposition rate for this species, using a $V_{d}$ of $0.15 \mathrm{~cm} \mathrm{~s}^{-1}$.

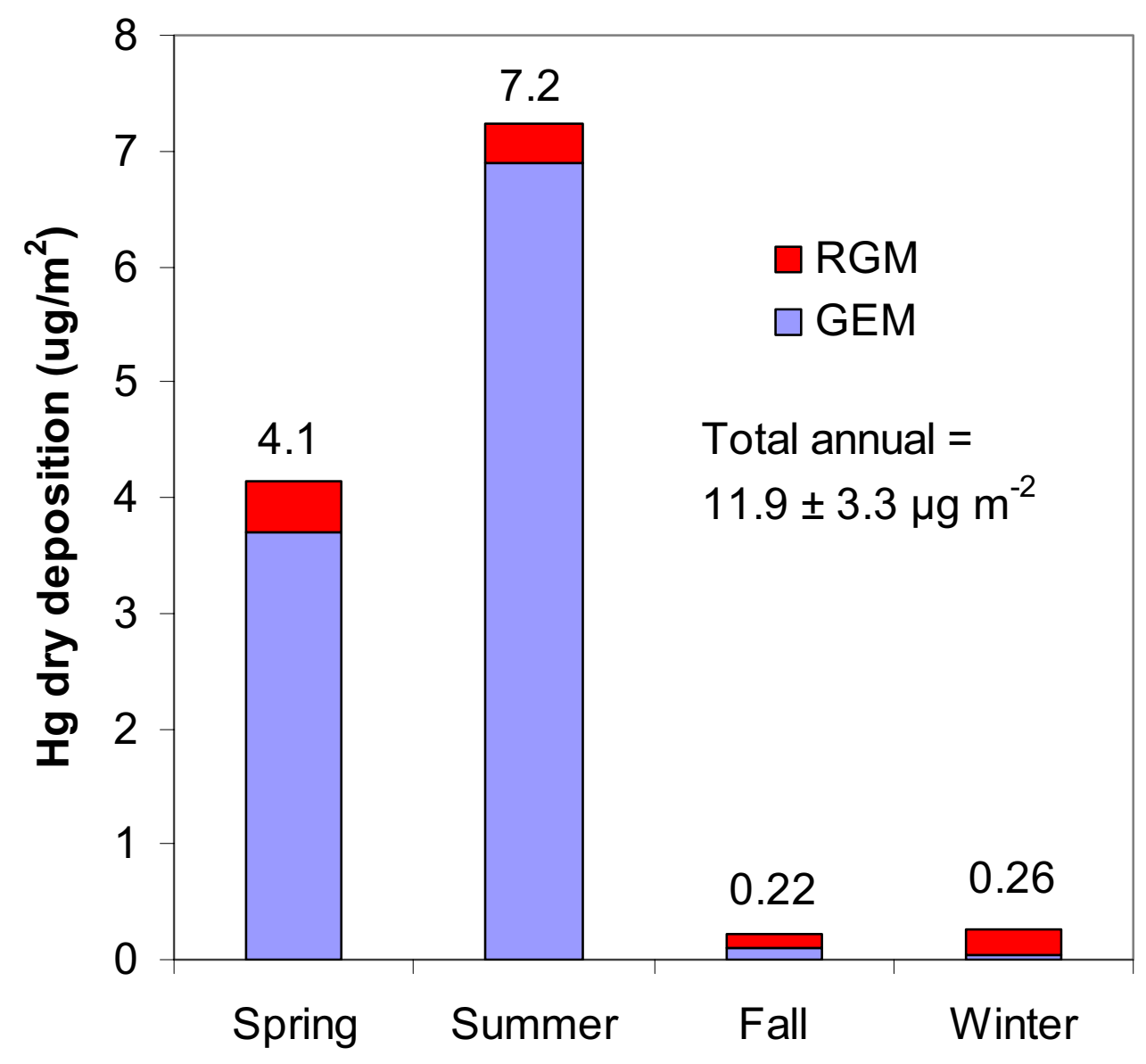

Figure 11. Calculated seasonal dry deposition at $\operatorname{SFCR}\left(\mu \mathrm{g} \mathrm{m}^{-2}\right)$. 
The annual-average modeled GEM dry deposition rate is $1.2 \pm 1.5 \mathrm{ng} \mathrm{m}^{-2} \mathrm{~h}^{-1}$. The total seasonal GEM deposition was estimated to be $3.7,6.9,0.10$, and $0.04 \mu \mathrm{g} \mathrm{m}^{-2}$ for spring, summer, fall, and winter, respectively (Figure 11). The annual GEM deposition is $10.8 \pm 3.3$ $\mu \mathrm{g} \mathrm{m}^{-2}$, which is higher than the multi-scale model estimates for this area $\left(\sim 5 \mu \mathrm{g} \mathrm{m}^{-2}\right)$ by Seigneur et al. (2001).

The total annual RGM + GEM dry deposition estimate for SFCR is $11.9 \pm 3.3 \mu \mathrm{g} \mathrm{m}^{-2}$, most (91\%) of which is contributed by GEM. This dry deposition estimate is higher than our annual wet deposition estimate for this area $\left(\sim 5 \mu \mathrm{g} \mathrm{m} \mathrm{m}^{-2}\right)$, which was made using 8 months (February through October 2006) of weekly precipitation measurements from an MDN-type monitor near the SFCR dam (Idaho DEQ, unpublished data). This is comparable to regional model estimates that about $2 / 3$ of the total deposition is dry (Lin et al., 2007).

It should be recognized that the estimated dry deposition may not reflect the measured airsurface exchange of mercury, which represents the net flux caused by the difference between the evasion (upward) flux and deposition (downward) flux. Based on the results of published flux (chamber and gradient) studies (Lindberg et al., 1995; Lindberg and Meyers, 2001; Zhang et al., 2001; Poissant et al., 2004), many have shown net GEM evasion at many sites.

\subsection{Flux measurements}

The micrometeorological flux measurements attempted in September 2006 to directly measure net surface exchange of $\mathrm{Hg}$ were only partially successful due to equipment malfunctions and time constraints. Seven hours after the start of the measurements, one of the 1130 denuder pump modules failed and could not be repaired for one week, which is all the time we had for using the EPA-borrowed Tekran system. We therefore continued with GEMonly gradient measurements, and obtained 7 days of data which showed GEM concentrations 
at the $1.5 \mathrm{~m}$ height were almost always higher than those measured at $3.5 \mathrm{~m}$ (Figure 12). The median concentration difference was $0.51 \mathrm{ng} \mathrm{m}^{-3}$ and the mean concentration difference was $0.58 \pm 0.4 \mathrm{ng} \mathrm{m}^{-3}(\mathrm{n}=81)$, far greater than the median absolute error between these two systems $\left(0.05 \mathrm{ng} \mathrm{m}^{-3}\right)$ measured during the collocated precision test (Figure 3). These positive gradients provide a strong indication that, during the 7 days of testing in September, there was net GEM evasion and no net dry deposition of GEM at the site. Because of the limited amount of data, we did not further pursue the calculation of the water vapor mass transfer coefficients from the EC station data or Hg flux. Since it is not known to what degree net positive evasion would occur at other times of the year (especially in the summer when most of the GEM dry deposition was calculated to occur), the net effect on annual GEM dry deposition is unknown. This is a significant data gap in the dry deposition assessment, although flux measurements are tentatively planned for future sampling activities at SFCR (EPA 10 Regional Applied Research Effort, [RARE]).

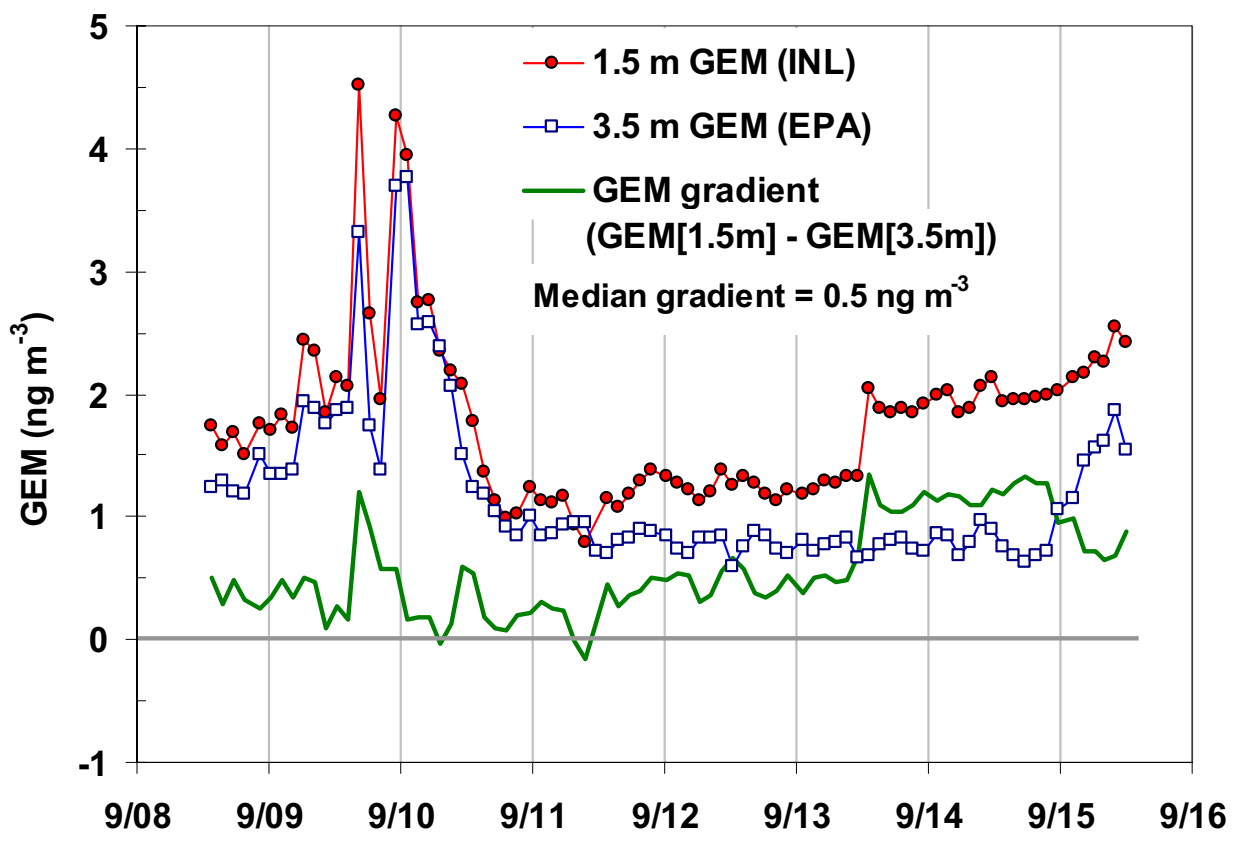

Figure 12. Results of 7-day GEM gradient measurements in September 2006. 


\subsection{Comparisons with other studies}

Table 3 summarizes the SFCR concentrations and calculated deposition values and compares them to values published for three other rural (non-industrialized) areas: (1) arid south-central New Mexico (Caldwell et al., 2006), (2) northern Nevada (Lyman et al., 2007), and (3) an eastern Canadian wetland (Poissant et al., 2004, 2005).

Table 3. Summary and comparison of measured air concentrations and calculated dry deposition values at SFCR with those from other areas.

\begin{tabular}{|c|c|c|c|c|c|c|c|c|}
\hline \multirow[b]{2}{*}{ Parameter } & \multirow[b]{2}{*}{ Summer } & \multirow[b]{2}{*}{ Fall } & \multirow[b]{2}{*}{ Winter } & \multirow[b]{2}{*}{ Spring } & \multirow[b]{2}{*}{ Annual } & \multicolumn{3}{|c|}{ Other studies } \\
\hline & & & & & & $\mathrm{NM}^{\mathrm{a}}$ & $N V^{b}$ & Canada $^{\mathrm{C}}$ \\
\hline GEM Concentrations $\left(\mathrm{ng} \mathrm{m}^{-3}\right)$ & $1.91 \pm 0.9$ & $1.53 \pm 0.5$ & $1.32 \pm 0.3$ & $1.39 \pm 0.7$ & $1.57 \pm 0.6$ & $1.59 \pm 0.4$ & $1.7-4.2$ & $1.65 \pm 0.4$ \\
\hline GEM dry deposition velocity $\left(\mathrm{cm} \mathrm{s}^{-1}\right)$ & $0.043 \pm 0.040$ & $0.0008 \pm 0.002$ & $0.0004 \pm 0.001$ & $0.034 \pm 0.032$ & -- & $0.01^{\mathrm{d}}$ & $0.01^{\mathrm{d}}$ & 0.19 \\
\hline GEM dry depostion $\left(\mu \mathrm{g} \mathrm{m}^{-2}\right)$ & 6.9 & 0.10 & 0.04 & 3.7 & $10.8 \pm 3.3$ & 5.0 & $0-5.8^{\mathrm{e}}$ & -- \\
\hline RGM Concentrations $\left(\mathrm{pg} \mathrm{m}^{-3}\right)$ & $8.1 \pm 5.6$ & $2.3 \pm 3.1$ & $3.2 \pm 2.9$ & $8.2 \pm 11.5$ & $6.8 \pm 12$ & 6.8 & $2-24$ & $3 \pm 11$ \\
\hline RGM dry deposition velocity $\left(\mathrm{cm} \mathrm{s}^{-1}\right)$ & $0.40 \pm 0.31$ & $0.51 \pm 0.43$ & $0.76 \pm 0.57$ & $0.50 \pm 0.39$ & -- & $0.5^{\mathrm{d}}$ & $0.30-1.72$ & 7.6 \\
\hline RGM dry depostion $\left(\mu \mathrm{g} \mathrm{m}^{-2}\right)$ & 0.33 & 0.12 & 0.22 & 0.44 & $1.1 \pm 0.1$ & 0.88 & $2.4^{\mathrm{f}}$ & -- \\
\hline $\begin{array}{l}\text { a. New Mexico (Caldwell et al., 2006). } \\
\text { b. Northern Nevada (Lyman et al., 2007) } \\
\text { c. Eastern Canadian wetland (Poissant } \\
\text { d. Assumed annual mean value. } \\
\text { e. Lower value from flux chamber measu } \\
\text { f. Modeled RGM + } \operatorname{HgP}(\sim 5-20 \% \text { of tot }\end{array}$ & $\begin{array}{l}\text { al., 2004, 2005) } \\
\text { ements at NV02 }\end{array}$ & MDN site; highe & alue from mod & ed GEM dep & on at NV99 & MDN site. & & \\
\hline
\end{tabular}

The summer GEM concentrations at SFCR $\left(1.91 \pm 0.09 \mathrm{ng} \mathrm{m}^{-3}\right)$ are slightly higher and more variable than those measured in south-central New Mexico $\left(1.75 \pm 0.1 \mathrm{ng} \mathrm{m}^{-3}\right)$ but are lower than those reported for northern Nevada in July and August $\left(3.3-4.2 \mathrm{ng} \mathrm{m}^{-3}\right)$. The annual-average GEM concentration at SFCR $\left(1.57 \pm 0.6 \mathrm{ng} \mathrm{m}^{-3}\right)$ is similar to that reported for New Mexico $\left(1.59 \pm 0.4 \mathrm{ng} \mathrm{m}^{-3}\right)$ and eastern Canada $(1.65 \pm 0.42)$, but lower than the seasonal values reported for northern Nevada $\left(1.7-4.2 \mathrm{ng} \mathrm{m}^{-3}\right)$. RGM concentrations at SFCR are lower than those reported for northern Nevada in the summer $\left(9-18 \mathrm{pg} \mathrm{m}^{-3}\right)$ and fall $(4-24$ $\left.\mathrm{pg} \mathrm{m}^{-3}\right)$. The annual-average RGM concentration at $\operatorname{SFCR}\left(6.8 \pm 12 \mathrm{pg} \mathrm{m}^{-3}\right)$ is similar to that measured at the New Mexico site $\left(6.8 \mathrm{pg} \mathrm{m}^{-3}\right)$ but is higher than that reported for the eastern 
Canadian site $\left(3 \pm 11 \mathrm{pg} \mathrm{m}^{-3}\right)$. The annual GEM deposition estimate for SFCR $(10.8 \pm 3.3 \mu \mathrm{g}$ $\left.\mathrm{m}^{-2}\right)$ is higher than that estimated for New Mexico $\left(5.0 \mu \mathrm{g} \mathrm{m}^{-2}\right)$ due to the higher summertime GEM concentrations observed at SFCR and our use of site-specific hourly $V_{d}$ values calculated from our on-site meteorology and seasonal surface conditions. RGM deposition at SFCR (1.1 $\pm 0.1 \mu \mathrm{g} \mathrm{m}^{-2}$ ) is similar to that estimated for New Mexico but less than that reported for Nevada $\left(2.4 \pm 0.1 \mu \mathrm{g} \mathrm{m}^{-2}\right)$.

\subsection{Back-trajectory and PSCF modeling}

The periodic GEM events (i.e., $>2.2 \mathrm{ng} \mathrm{m}^{-3}$ ) observed during the sampling (Figures $5-7$ ) are likely due to transport of enriched $\mathrm{Hg}$ air masses from regional sources that passed through the sampling site. The events are not due to global source (trans-Pacific) inputs, based on long-term measurements of trans-Pacific air at the Mount Bachelor Observatory (MBO) in Oregon (range $\sim 1.4 \mathrm{ng} \mathrm{m}^{-3}$ to $2.2 \mathrm{ng} \mathrm{m}^{-3}$; see http://research.uwb.edu/jaffegroup/modules/Rawdata/). The short-term persistence of the majority of the events (i.e., 1 to 5 hours) may suggest intermittent passage (at the sampling site) of relatively narrow point source plumes with changing wind directions. Diffuse sources (e.g., wildfires, surface evasion from large naturally enriched areas) have much wider plumes that would likely have produced flatter and longer-term event profiles.

HYSPLIT 24-hr back-trajectories for the enhanced 1-hr GEM samples (Figure 13) show that most of the back-trajectories lie to the southwest (north-central Nevada) and southeast (western Utah, extreme northeastern Nevada) with fewer inputs from the northwest (Oregon, southwestern Idaho). In summer 2005, back-trajectories for all 1-hr event samples were about evenly distributed between the northwest, southwest, and southeast, although there were a greater number of overall event peaks (maximum 1-hour concentration over a single event) 
from the southwest. From fall 2005 through summer 2006, most of the events came from the southwest. In fall 2006, one relatively long (21 hr) event occurred on 9/19 (mean GEM concentration $=3.3 \mathrm{ng} \mathrm{m}^{-3}$ ), which was associated with stable wind flow conditions from the southeast. 


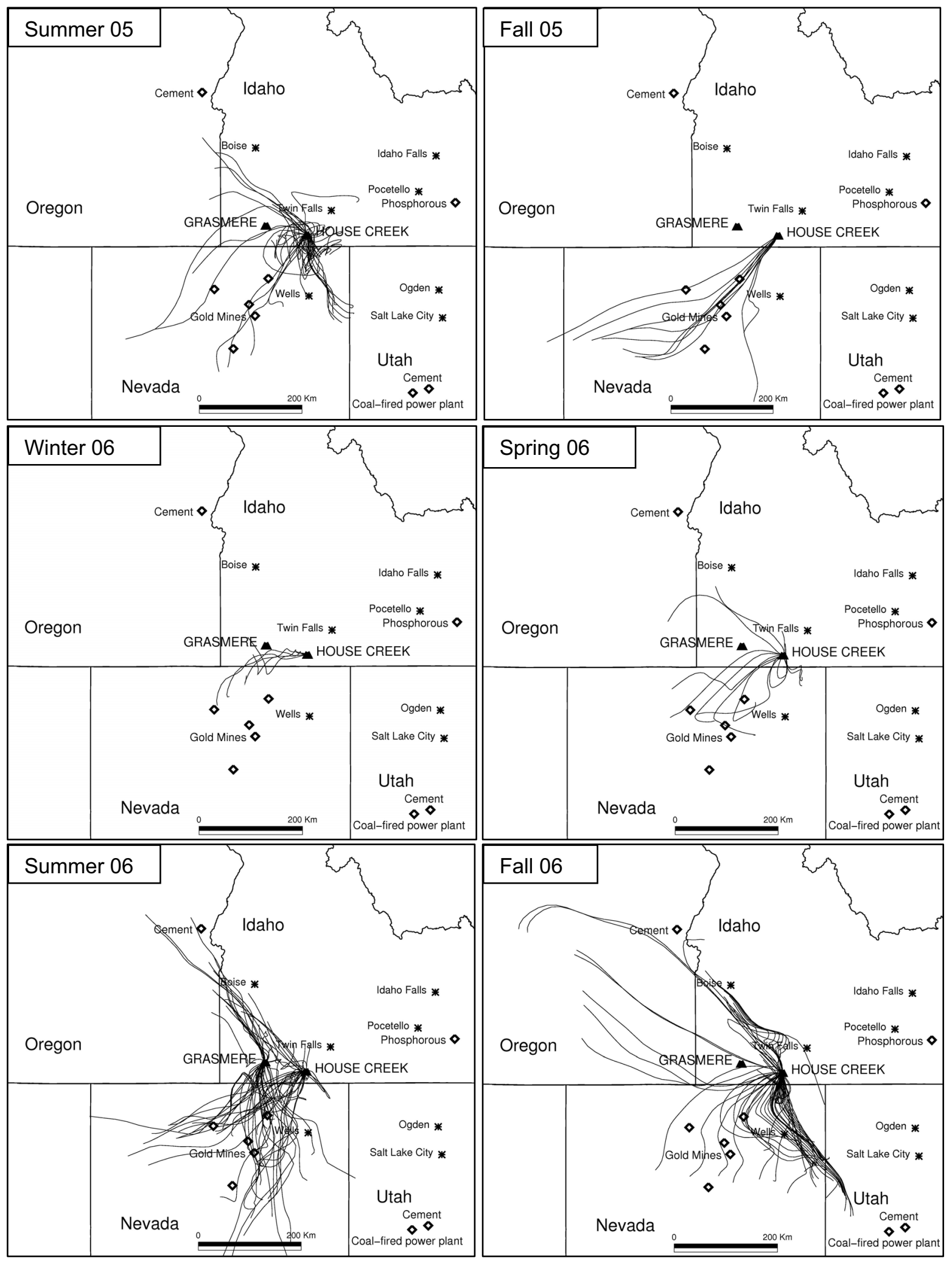

Figure 13. 24-hour HYSPLIT4 back-trajectories of upwind air parcels associated with GEM concentrations $>2.2 \mathrm{ng} \mathrm{m}^{-3}$ over the six seasonal sampling campaigns. 
The PSCF analysis indicates that the upwind areas with the highest probability of inputs are from the southeast through the southwest, with lesser inputs from the northwest (Figure 14).

The high PSCF values to the southeast were strongly influenced by the single 21 hour event on 9/19 that was associated with stable southeasterly winds (Figure 13, Fall 06).

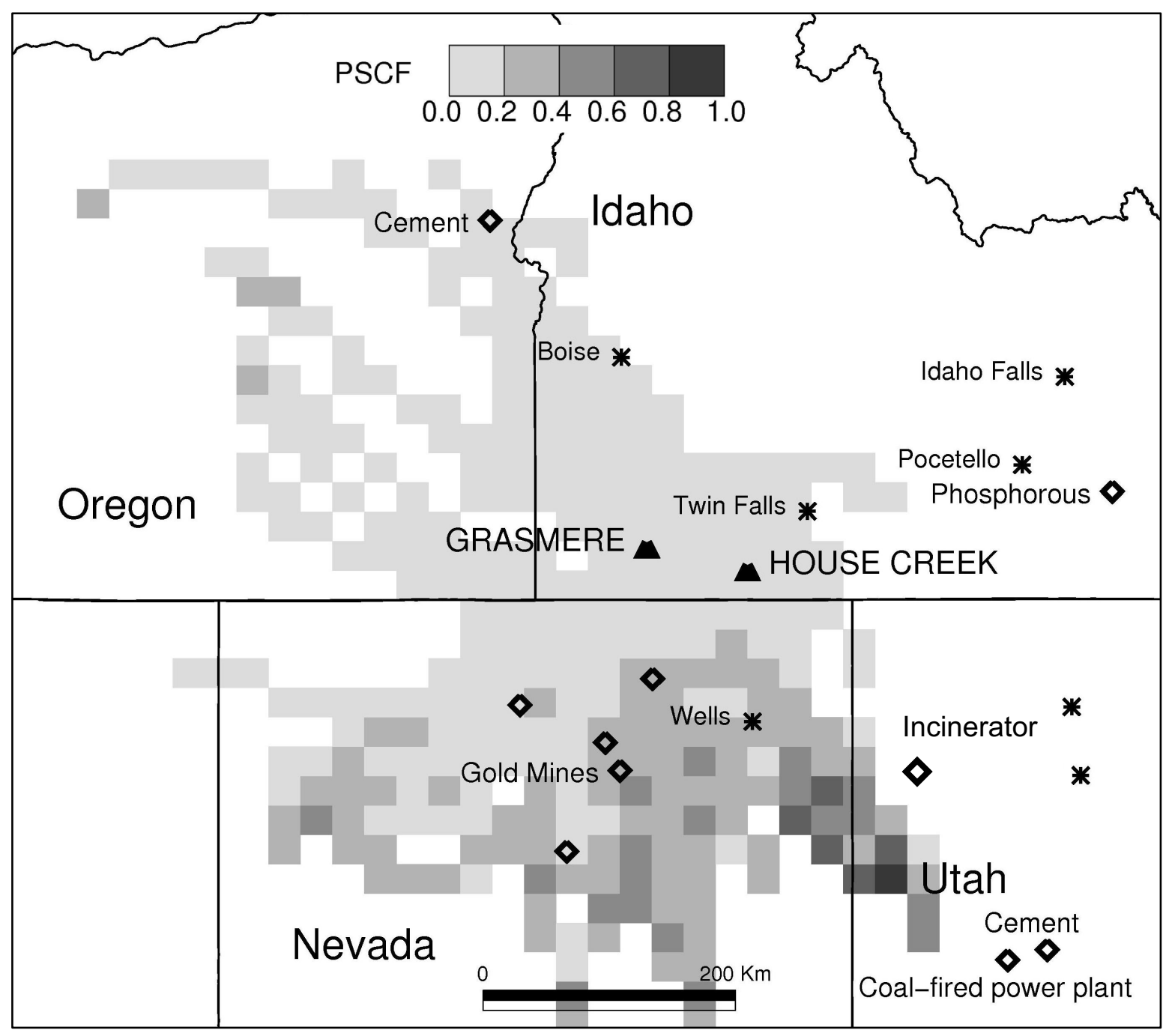

Figure 14. Potential source contribution function (PSCF) map for GEM concentrations > $2.2 \mathrm{ng} \mathrm{m}^{-3}$ over the six seasonal sampling campaigns (summer 2005 through summer 2006). Darker colors indicate greater source potential. 
Anthropogenic sources in the area to the southeast that report atmospheric $\mathrm{Hg}$ emissions are primarily in Utah: (1) an $1800 \mathrm{MW}$ coal-fired power plant near Delta (390 km from SFCR), (2) a large cement plant near Leamington (370 km), and (3) a hazardous waste incinerator 80-km west of Salt Lake City (Aragonite Plant) (135 km from SFCR). The total TRI-reported $\mathrm{Hg}$ atmospheric emissions from these Utah sources in 2005 were $246 \mathrm{~kg}$ which is relatively low compared to other sources in the region. There are also a few abandoned gold mining areas in extreme western Utah (Clifton, Willow Springs, Spring Creek), although these are unlikely sources due to their small scale and short history of operations.

To the south and southwest, the northern Nevada gold mines $(120-150 \mathrm{~km}$ from SFCR) are the largest known anthropogenic sources (2100 kg in 2005, mostly stack point sources). There are also known naturally-enriched diffuse $\mathrm{Hg}$ sources in this area (Zehner and Gustin, 2002). One of the major ones is the Ivanhoe Mining District where Engle et al. (2001) measured annual $\mathrm{Hg}$ emissions of $78 \mathrm{~kg}$ averaged over a $586 \mathrm{~km}^{2}$ area. The maximum GEM air concentration measured directly on the surface at undisturbed sites in this area was $9 \mathrm{ng} \mathrm{m}^{-3}$ (Engle et al., 2001). Since air dispersion would reduce these concentrations significantly (at least 2 orders of magnitude) over the $120 \mathrm{~km}$ transport distance to SFCR, it seems unlikely that natural sources in this area would be a major contributor to the events we observed.

Wildfires are also known to release $\mathrm{Hg}$ (Friedli et al., 2003) and were also very prevalent in north-central Nevada in 2005-2006. These may have contributed to some of the events observed in the summer months, although they are not believed to be a major contributor based on: (1) the lack of elevated $\mathrm{HgP}$, a significant component ( $9 \%$ ) of wildfire emissions (Friedli et al. 2003), in the numerous events observed at GRAS, (2) our measurements $10 \mathrm{~km}$ directly downwind from the Reynolds Spring wildfire on September 4-5 (maximum GEM 
concentration $2.7 \mathrm{ng} \mathrm{m}^{-3}$ ), and (3) other $\mathrm{Hg}$ measurements made downwind from wildfires in eastern Washington (Friedli et al. 2003) and Nevada (Lyman et al., in press).

\section{Conclusions}

Speciated GEM and RGM measurements conducted over six seasons in the remote SFCR area show relatively high and variable concentrations during the warm seasons (summer, early fall) and low background concentrations during the cold seasons (late fall - winter). GEM was weakly correlated with meteorological parameters, but RGM showed a stronger correlation with air temperature, solar radiation, and ozone concentrations, suggesting the role of photochemistry in its production. Our total annual dry deposition estimate of $11.9 \mu \mathrm{g} \mathrm{m}^{-2}$ is about $2 / 3$ of the total (wet + dry) deposition estimate for this area and similar to that predicted by regional models, although ours is dominated by GEM in the warm seasons. These dry deposition estimates do not account for GEM evasion losses (upward flux) which could be substantial based on results from other published studies.

Periodic elevated GEM events $\left(2.2-12 \mathrm{ng} \mathrm{m}^{-3}\right)$ were observed primarily in the summer/early fall. Back-trajectory modeling and PSCF analysis indicate predominant source contributions from the southeast (western Utah, northeastern Nevada) and southwest (northcentral Nevada) with fewer inputs from northwest (Oregon and southwestern Idaho).

Numerous known anthropogenic and natural $\mathrm{Hg}$ sources exist in these areas, and there are likely additional undocumented sources. Because of this and the relatively long wind transport distances that characterize this relatively remote area, additional receptor modeling techniques (e.g., multi-variate chemical signatures, positive matrix factorization) will likely be needed to further clarify source category inputs. 


\subsection{References}

Abbott, M.L., 2003. Environmental Sampling FY-03 Annual Report—Understanding the movement of mercury at the INEEL. INEEL/EXT-03-01250, October 2003. Available at http://www.inl.gov/technicalpublications/Search/Search.asp.

Ashbaugh, L.L., Malm, W.C., Sadeh, W.Z., 1985. A residence time probability analysis of sulfur concentrations at Grand Canyon national park. Atmos. Environ. 19, 1263-1270.

Caldwell, C.A., Swartzendruber, P., Prestbo, E., 2006. Concentration and dry deposition of mercury species in arid south-central New Mexico (2001-2002). Environ. Sci. Technol. 40, $7535-7540$.

Draxler, R.R., Rolph, G.D., 2003. HYSPLIT (Hybrid Single-Particle_Lagrangian Integrated Trajectory). Model access via NOAA ARL READY website http://www.arl.noaa.gov/ready/hysplit4.html, NOAA Air Resources Laboratory, Silver Spring, MD.

Driscoll, C.T., Yan, C., Schofield, C.L., 1994. The mercury cycle and fish in the Adirondack lakes. Environ. Sci. Technol. 28(3), 136A-143A.

Engle, M.A., Gustin, M.S., Zhang, H., 2001. Quantifying natural source emissions from the Ivanhoe Mining District, north-central Nevada, USA. Atmos. Environ. 35, 3987-3997.

Engstrom, D.R., Swain, E.B., 1997. Recent declines in atmospheric mercury deposition in the upper Midwest. Environ. Sci. Technol. 31, 960-967.

Fitzgerald, W.F., Engstrom, D.R., Mason, R.P., Nater, E.A., 1998. The case for atmospheric mercury contamination in remote areas. Environ. Sci. Technol. 32, 1-7. 
Friedli, H.R., Radke, L.F., Prescott, R., Hobbs, P.V., Sinha, P., 2003. Mercury emissions from the August 2001 wildfires in Washington State and an agricultural waste fire in Oregon and atmospheric mercury budget estimates. Global Biogeochem. Cycles 17, 1039.

Gallagher, M.W., Nemitz, E., Dorsey, J.R., Fowler, D., Sutton, M.A., Flynn, M. Duyzer, J., 2002. Measurements and parameterizations of small aerosol deposition velocities to grassland, arable crops, and forest: Influence of surface roughness length on deposition. Journal of Geophysical Research-Atmospheres, 107(D12).

Ganzeveld, L. and Lelieveld, J., 1995. Dry Deposition Parameterization in a Chemistry General-Circulation Model and Its Influence on the Distribution of Reactive Trace Gases. Journal of Geophysical Research-Atmospheres, 100, 20999-21012.

Gao, N., Armatas, G., Shanley, J., Kamman, N., Miller, E., Keeler, G., Scherbatskoy, T., Holsen, T., Yound, T., McIlroy, L., Drake, S., Olsen, B., Cady, C., 2006. Mass balance assessment for mercury in Lake Champlain. Environ. Sci. Technol. 40, 82-89.

Golder, G., 1972. Relations among stability parameters in the surface layer. Boundary Layer Meteorology, 3, 47-58.

Guentzel, J.L., Landing, W.M., Gill, G.A., Pollman, C.D., 2001. Processes influencing rainfall deposition of mercury in Florida. Environ. Sci. Technol. 35, 863-873.

Gustin, M., 2003. Are mercury emissions from geologic sources significant? A status report. Sci. Total Environ. 304, 153-167.

Hall, B.D., Olson, M.L., Rutter, A.P., Frontiera, R.R., Krabbenhoft, D.P., Gross, D.S., Yuen, M., Rudolph, T.M., Schauer, J.J., 2006. Atmospheric mercury speciation in Yellowstone National Park. Sci. Total Environ. 367, 354-366. 
Hopke, P.K., Gao, N., Cheng, M.D., 1993. Combining chemical and meteorological data to infer source areas of airborne pollutants. Chemom. Intel. Lab. Syst. 19, 187-199.

Hsu, Y-K, Holsen, T.M., Hopke, P.K., 2003. Locating and quantifying PCB sources in Chicago: receptor modeling and field sampling. Environ. Sci. Technol. 37, 681-690.

Jaffe, D., Prestbo, E., Swartzendruber, P., Weiss-Penzias, P., Kato, S., Takami, A., Hatakeyama, S., Kajii, Y., 2005. Export of atmospheric mercury from Asia, Atmos. Environ. 39, 3029-3038.

Kang, W.-J., Trefry, J.H., Nelsen, T.A., 2000. Direct atmospheric inputs versus runoff fluxes of mercury to the lower Everglades and Florida Bay. Environ. Sci. Technol. 34, 4058-4063.

Landis, M.W., Stevens, R.K., Schaedlich, F., Prestbo, E.M., 2002. Development and characterization of an annular denuder methodology for the measurement of divalent inorganic reactive gaseous mercury in ambient air. Environ. Sci. Technol. 36, 3000-3009.

Lin, C., Pongprueksa, P., Lindberg, S.E., Pehkonen, S.O., Byun, D., Jang, C., 2006. Scientific uncertainties in atmospheric mercury models I: Model science evaluation. Atmospheric Environment, 40, 2911-2928.

Lin C.-J., Pongprueksa P., Bullock R. O., Lindberg S. E., Pehkonen S. O., Jang C., Braverman T. and Ho T. C., 2007. Scientific uncertainties in atmospheric mercury models II: Sensitivity analysis in the CONUS domain. Atmospheric Environment, in press.

Lindberg, S.E., Meyers, T.P., Taylor, G.E., Turner, R.R., Schroeder, W.H., 1992. Atmospheresurface exchange of mercury in a forest: results of modeling and gradient approaches. Journal of Geophysical Research 97 (D2), 2519-2528. 
Lindberg, S.E., Kim, K.-H., Munthe, J., 1995. The precise measurement of concentration gradients of mercury in air over soils: A review of past and recent measurements. Water Air Soil Pollut. 80, 383-392.

Lindberg, S.E., Meyers, T.P., 2001. Development of an automated micrometeorological method for measuring the emission of mercury vapor from wetland vegetation. Wetlands Ecology and Management 9, 333-347.

Lockhart, W.L., Wilkinson, P., Billeck, B.N., Hunt, R.V., Wagemann, R., Bruskill, G.J., 1995. Current and historical inputs of mercury to high latitude lakes in Canada and to Hudson Bay. Water, Air, and Soil Pollution 80, 603-610.

Lyman, S.N., Gustin, M.S., Presto, E.M., Marsik, F.J., 2007. Estimation of dry deposition of atmospheric mercury in Nevada by direct and indirect methods. Environ. Sci. Technol. 41, 1970-1976.

Mason, R.P., Fitzgerald, W.F., Morel, F.M., 1994. The boegeochemical cycling of elemental mercury: anthropogenic influences. Geochim Cosmochim Acta 58, 3191-3198.

Mason, R.R., Sullivan, K.A., 1997. Mercury in Lake Michigan. Environ. Sci. Technol. 31, 942947.

Pai, P., Karamchandani, P., Seigneur, C., 1997. Simulation of the regional atmospheric transport and fate of mercury using a comprehensive Eulerian model. Atmos. Environ. 31, $2727-2732$.

Poissant, L., Pilote, M., Xu, X., Zhang, H., 2004. Atmospheric mercury speciation and deposition in the Bay St. Francois wetlands. J. Geophys. Res. 109, D11301,. 
Poissant, L., Pilote, M., Beauvais, C., Constant, P., Zhang, H., 2005. A year of continuous measurements of three atmospheric mercury species (GEM, RGM, and $\mathrm{Hg}_{\mathrm{p}}$ ) in southern Quebec, Canada. Atmos. Environ. 39, 1275-1287.

Schroeder, W.H., Munthe, J., 1998. Atmospheric mercury-an overview. Atmos. Environ. 32, 809-822.

Schuster, P., Krabbenhoft, D., Naftz, D., Cecil, D., Olson, M., Dewild, J., Susong, D., Green, J., Abbott, M., 2002. Atmospheric mercury deposition during the last 270 years: A Glacial ice core record of natural and anthropogenic sources. Environ. Sci. Technol. 36, 23032310.

Seinfeld, J.J. and Pandis, S.N., 1998. Atmospheric Chemistry and Physics. John Wiley \& Sons, Inc., New York.

Seigneur, C., Karamchandani, P., Lohman, K., Vijayaraghavan, K., 2001. Multiscale modeling of the atmospheric fate and transport of mercury. J. Geophys. Res. 106, D21, 27,79527,809 .

Seigneur, C., Vijayaraghavan, K., Lohman, K., Karamchandani, P., Scott, C., 2004. Global source attribution for mercury deposition in the United States. Environ. Sci. Technol. 38, 555-569.

Swain, E.B., Engstrom, D.R., Brigham, M.E., Henning, T.A., Brezonik, P.L., 1992. Increasing rates of atmospheric mercury deposition in Midcontinental North America, Science 257, 784-787.

Tekran, 1999. Model 2537A Mercury Vapour Analyzer User Manual, Toronto, Canada. 
USEPA, 1998. U.S. Environmental Protection Agency. Mercury Study Report to Congress; EPA-452/R-97-003, Office of Air Quality and Standards, Office of Research and Development, U.S. Government Printing Office, Washington, DC.

Vette, A.F., Landis, M.S., Keeler, G.J., 2002. Deposition and emission of gaseous mercury to and from Lake Michigan during the Lake Michigan Mass Balance Study (July, 1994October, 1995). Environ. Sci. Technol. 36, 4525-4532.

Wang, Y.Q., Zhang, X.Y., Arimoto, R., 2006. The contribution from distant dust sources to the atmospheric particulate matter loadings at XiAn, China during spring. Sci. Total Environ. $368,875-883$.

Weiss-Penzias, P., Jaffe, D., Swartzendruber, P., Dennison, J.B., Chand, D., Hafner, W., Prestbo, E., 2006. Observations of Asian air pollution in the free troposphere at Mt. Bachelor Observatory in the spring of 2004. J. Geophys. Res. 110, D10304.

Wesely, M.L., 1989. Parameterization of surface resistances to gaseous dry deposition in regional-scale numerical models. Atmospheric Environment 23, 1293-1304.

Zehner, R.E., Gustin, M.S., 2002. Estimation of mercury vapor flux from natural substrate in Nevada. Environ. Sci. Technol. 36, 4039-4045.

Zhang, L., Gong, S., Padro, J., Barrie, L., 2001. A size-segregated particle dry deposition scheme for an atmospheric aerosol module. Atmos. Environ. 35, 549-560.

Zhang, L., Brook, J.R. and Vet, R., 2003. A revised parameterization for gaseous dry deposition in air-quality models. Atmospheric Chemistry and Physics, 3: 2067-2082. 